\title{
Impact of dual mTORC1/2 mTOR kinase inhibitor AZD8055 on acquired endocrine resistance in breast cancer in vitro
}

Nicola J Jordan ${ }^{1,4}$, Carol M Dutkowski ${ }^{1}$, Denise Barrow ${ }^{1}$, Huw J Mottram', lain R Hutcheson², Robert I Nicholson , Sylvie M Guichard ${ }^{3}$ and Julia MW Gee ${ }^{1 *}$

\begin{abstract}
Introduction: Upregulation of PI3K/Akt/mTOR signalling in endocrine-resistant breast cancer (BC) has identified mTOR as an attractive target alongside anti-hormones to control resistance. RAD001 (everolimus/Afinitor ${ }^{\circledR}$ ), an allosteric mTOR inhibitor, is proving valuable in this setting; however, some patients are inherently refractory or relapse during treatment requiring alternative strategies. Here we evaluate the potential for novel dual mTORC1/2 mTOR kinase inhibitors, exemplified by AZD8055, by comparison with RAD001 in ER + endocrine resistant BC cells.
\end{abstract}

Methods: In vitro models of tamoxifen (TamR) or oestrogen deprivation resistance (MCF7-X) were treated with RAD001 or AZD8055 alone or combined with anti-hormone fulvestrant. Endpoints included growth, cell proliferation (Ki67), viability and migration, with PI3K/AKT/mTOR signalling impact monitored by Western blotting. Potential ER cross-talk was investigated by immunocytochemistry and RT-PCR.

Results: RAD001 was a poor growth inhibitor of MCF7-derived TamR and MCF7-X cells (IC $50 \geq 1 \mu \mathrm{M}$ ), rapidly inhibiting mTORC1 but not mTORC2/AKT signalling. In contrast AZD8055, which rapidly inhibited both mTORC1 and mTORC2/AKT activity, was a highly effective $(P<0.001)$ growth inhibitor of TamR $\left(I C_{50} 18 \mathrm{nM}\right)$ and MCF7-X $\left(I C_{50} 24 \mathrm{nM}\right)$, and of a further T47D-derived tamoxifen resistant model T47D-tamR $\left(I C_{50} 19 \mathrm{nM}\right)$. AZD8055 significantly $(P<0.05)$ inhibited resistant cell proliferation, increased cell death and reduced migration. Furthermore, dual treatment of TamR or MCF7-X cells with AZD8055 plus fulvestrant provided superior control of resistant growth versus either agent alone $(P<0.05)$. Co-treating with AZD8055 alongside tamoxifen $(P<0.01)$ or oestrogen deprivation $(P<0.05)$ also effectively inhibited endocrine responsive MCF-7 cells. Although AZD8055 inhibited oestrogen receptor (ER) ser167 phosphorylation in TamR and MCF7-X, it had no effect on ER ser118 activity or expression of several ER-regulated genes, suggesting the mTOR kinase inhibitor impact was largely ER-independent. The capacity of AZD8055 for ER-independent activity was further evidenced by growth inhibition ( $\mathrm{IC}_{50} 18$ and $20 \mathrm{nM}$ ) of two acquired fulvestrant resistant models lacking ER.

Conclusions: This is the first report demonstrating dual mTORC1/2 mTOR kinase inhibitors have potential to control acquired endocrine resistant BC, even under conditions where everolimus fails. Such inhibitors may prove of particular benefit when used alongside anti-hormonal treatment as second-line therapy in endocrine resistant disease, and also potentially alongside anti-hormones during the earlier endocrine responsive phase to hinder development of resistance.

\footnotetext{
* Correspondence: gee@cardiff.ac.uk

'Breast Cancer (Molecular Pharmacology) Group, Cardiff School of Pharmacy and Pharmaceutical Sciences, Cardiff University, Redwood Building, King Edward VII Avenue, Cardiff CF10 3NB, UK

Full list of author information is available at the end of the article
} 


\section{Introduction}

Growth of the majority of breast cancers is stimulated by oestrogen and this oestrogen receptor (ER) signalling can be successfully blocked by anti-hormonal treatments, including aromatase inhibitors or the oestrogen receptor antagonists, tamoxifen or fulvestrant. Anti-hormone treatment is effective in a high proportion of initially responsive patients but subsequently a significant number acquire resistance with resulting poorer survival rates [1]. Consequently, there is an urgent need for treatments for breast cancer that improve responses to prevent or delay endocrine resistance. In an attempt to overcome endocrine resistance, studies have focussed on developing novel agents that can reverse resistance by targeting growth factor signalling pathways. Endocrine resistant cells can be highly dependent on the use of activated growth factor signalling pathways including epidermal growth factor receptor (EGFR) and human epidermal growth factor receptor-2 (HER2) [2]. The phosphatidylinositol 3-kinase (PI3K)/Akt/mammalian target of rapamycin (mTOR) signalling network is also often prominent in endocrine resistant breast cancer, extending to tamoxifen resistant and oestrogen deprivation resistant MCF-7-derived cell lines [3-5]. In patients with invasive breast cancer, increased activation of this pathway is associated with poor prognosis [6] and, thus, mTOR has recently been recognised as an important drug target for breast cancer therapy [7].

mTOR is a highly conserved serine/threonine protein kinase that belongs to the PI3K- related family and serves as a central regulator of cell metabolism, growth, proliferation and survival [8]. Extensive knowledge about the function of this protein has come from the experimental use of the natural bacterial antibiotic rapamycin, which inhibits the activity of mTOR. mTOR consists of two separate multi-protein complexes, mTORC1 and mTORC2, that are both activated by growth factor stimulation. The mTORC1 complex is rapamycin sensitive; rapamycin binds the FK506-binding protein (FKBP-12) which binds to and causes allosteric inhibition of the signalling complex mTORC1 [9] which contains mTOR, the regulatory associated protein (RAPTOR), mLST8, PRAS40 and DEPTOR proteins. mTORC1 positively regulates protein translation and synthesis via its main substrates, p70 ribosomal S6 kinase (p70S6K) and the eukaryotic initiation factor 4E binding protein-1 (4E-BP1). Upon phosphorylation, 4E-BP1 dissociates from the mRNA cap-binding protein eIF4E and allows it to interact with eIF4G to form a translation initiation complex [10]. In the less well-defined rapamycin-insensitive mTORC2 complex [11], mTOR is associated with the rapamycin insensitive companion (RICTOR), LST8, mSIN1, PROCTOR and DEPTOR and phosphorylation of 4E-BP1 on t37/46 is also considered rapamycin insensitive [12]. The mTORC2 complex is involved in cytoskeletal organisation via paxillin, rho/rac and $\mathrm{PKB} \alpha$, but it also plays a key role in cell proliferation and survival via activation of serum and glucocorticoid protein kinase 1 (SGK1) and direct activation of Akt [8]. However, the characterisation of mTORC1 and mTORC2 as rapamycin-sensitive and insensitive complexes may not always be entirely accurate, as chronic rapamycin treatment has also been reported to inhibit mTORC2 activity by blocking its assembly $[8,13]$.

The mTOR inhibitor rapamycin (sirolimus) has been used clinically as an immunosuppressant drug in transplant medicine [14]. However, it has recently been realised that the increased activity of the mTOR pathway caused by upstream changes in regulators, such as phosphatidylinositol-3 (PI3)-phosphatase (PTEN) and PI3K, also makes mTORC1 an attractive anti-cancer target [15] and a number of rapamycin analogues (rapalogues) have been produced: RAD001 (everolimus, Afinitor ${ }^{\circ}$, Novartis), CCI-779 (temsirolimus, Wyeth) and AP23573 (MK-8669) (ridaforolimus ARIAD and Merck pharmaceuticals). The first clinical cancer trials in metastatic breast cancer with temsirolimus as a monotherapy resulted in only partial responses [16,17]. The unexpectedly modest outcomes, with patients acquiring resistance or exhibiting intrinsic resistance to these allosteric mTORC1 inhibitors, may be associated with a paradoxical increase in the activation of Akt and PI3K caused by inhibition of a negative feedback loop from S6 kinase to IRS-1 in response to mTORC1 inhibition by rapalogues [18-21], with the subsequent enhanced Akt activation reportedly being associated with rapalogue monotherapy failure in some patients [22-24].

However, while monotherapy studies with several signal transduction inhibitors, including rapalogues, have shown only modest success in advanced breast cancers, preclinical data indicate that a combination of anti-hormone and signal transduction inhibitors (STI's) can provide significantly greater inhibition than either agent alone [21]. Although breast cancers may become resistant to first-line antihormone treatment they often retain an active ER and will still respond to an alternative endocrine agent as a secondline therapy, but longer-term success is more likely to be achieved by also targeting up-regulated growth factor pathways that can be independent from, or interactive with, ER signalling pathways. Pre-clinical data were supportive of the use of current mTOR antagonists alongside endocrine therapy in breast cancer which resulted in a number of clinical trials using such combination therapies [25]. One of the earliest phase 3 trials combined letrozole and temsirolimus and was used on advanced breast cancer but the trial had to be terminated early due to failure to demonstrate any benefit [19]. Later studies have been more successful with very promising results obtained recently in advanced endocrine resistant disease where RAD001 (everolimus) was used in combination with the steroidal aromatase inhibitor 
exemestane or with tamoxifen in phase $2 / 3$ trials. These have shown significant improvement in progression-free survival from 4.1 months with exemestane alone to 10.6 months with a combination of exemestane and everolimus in the BOLERO 2 trial [26] and an improved time to progression from 4.5 months with tamoxifen alone to 8.6 months with tamoxifen plus everolimus in the TAMRAD GINECO trial [27]. These clinical findings indicated value for the allosteric mTOR inhibitors used alongside tamoxifen or aromatase inhibitors in advanced endocrine resistant tumours and there has been recent USA Food and Drug Administration approval for everolimus in combination with exemestane in ER+/HER2- metastatic breast cancer after non-steroidal aromatase inhibitor failure [28].

Nevertheless, there remains a group of patients who are initially refractory to everolimus/anti-hormone therapy while others relapse at a later point during such treatment [26,27]. It is feasible that these patients may gain more benefit from treatment with alternative mTOR inhibitors that, unlike rapalogues, are not restricted to inhibition of only mTORC1 signalling. It is thus interesting that several types of new mTOR inhibitors are currently under development. The dual mTOR and PI3K inhibitors (SF1126-Semafore, NVP-BEZ235Novartis, xL765-Exelis-Sanofi and GDC-0980- RocheGenentech) simultaneously block both the PI3K and mTOR signalling and, therefore, have the theoretical advantage of totally shutting down the PI3K/Akt/mTOR network [14]. These have the possible drawback of association with greater toxicity but in early small clinical trials are reported to induce stable disease or partial response (see [14]). A new variety of mTOR inhibitors has also recently emerged which are ATP-competitive inhibitors that target the mTOR kinase domain and, thus, dually-inhibit activity of both mTORC1 and mTORC2 complexes. This approach should be an alternative way to mitigate the problem of Akt/PI3K activation by negative feedback seen with rapalogues. Preclinical data for two such agents, PP242 and PP30, suggest that along with the additional benefit of $\mathrm{mTORC} 2$ inhibition, these drugs can also be more effective than rapamycin at inhibiting mTORC1 activity [14,29,30]. Several pan mTOR (mTORC1/2) dual kinase inhibitors (AZD8055 and its related compound AZD2014 (Astra Zeneca), as well as INK128 (Intellikine) and OSI-027 (OSI Pharmaceuticals)) are currently in phase I/II studies on solid tumours and breast cancer or lymphoma [30-33]. However, the value of such dual mTORC1/2 inhibitory strategies remains unknown in the context of endocrine resistance in breast cancer.

Here, for the first time we show that in comparison with RAD001, an mTOR kinase inhibitor AZD8055 is significantly superior as a single agent, modulating both mTORC1 and mTORC2 signalling, cell growth and survival in tamoxifen (TamR) and oestrogen deprivation (MCF7-X) resistant cell lines that aim to model clinical relapse following first-line endocrine treatment. Furthermore, we demonstrate that in these endocrine resistant RAD001-resistant models, AZD8055 results in superior growth inhibition when used alongside fulvestrant and is additionally effective alongside anti-hormones during the earlier, endocrine responsive phase of this disease in vitro. Cumulatively, these data suggest considerable potential for mTOR kinase inhibitors that target both mTORC1 and 2 to subvert resistance during antihormonal management of breast cancer.

\section{Methods}

\section{Cell culture}

The parental ER + breast cancer cell lines were from American Type Culture Collection (ATCC) (Manassas, Virginia, USA) (T47D) or a gift from AstraZeneca (MCF-7) Alderly Park, Macclesfield, (Cheshire, UK). Experimental cells were grown in phenol red-free RPMI-1640 supplemented with 5\% FCS (foetal calf serum), penicillin/streptomycin $(10 \mathrm{U} / \mathrm{ml}$ and $10 \mu \mathrm{g} / \mathrm{ml})$, fungizone $(2.5 \mu \mathrm{g} / \mathrm{ml})$ and $4 \mathrm{mM}$ glutamine. All cell culture reagents and FCS were from Invitrogen Life Technologies (Fisher Scientific, Loughborough, UK). Cell lines were used within a window of 20 passages. The acquired ER + tamoxifen-resistant cell line, TamR, was derived from MCF-7 cells continuously exposed to $10^{-7} \mathrm{M}$ 4-hydroxytamoxifen (Sigma-Aldrich, Gillingham, Dorset, UK) until emergence (from six months) of a cell line resistant to the growth inhibitory properties of this anti-hormone as previously described [34]. ER + acquired tamoxifen-resistant T47D-tamR cells were also available for this study, similarly derived by our group from T47D cells following continuous exposure to $10^{-7} \mathrm{M} 4$ hydroxytamoxifen. Stable TamR cells were routinely maintained in phenol-red free RPMI-1640, 5\% charcoal-stripped FCS (sFCS) and $10^{-7} \mathrm{M}$ 4-hydroxytamoxifen, with T47D-tamR cells also maintained in the presence of this anti-hormone. The ER + model used for acquired resistance to severe oestrogen deprivation was MCF7-X, derived from MCF-7 cells grown in phenol-red free RPMI containing $5 \%$ heat inactivated $\left(65^{\circ} \mathrm{C}, 40\right.$ minutes) charcoal stripped FCS (X medium) as described previously [3]. Two ER negative acquired fulvestrant (Faslodex)-resistant cell lines were also available for study generated from MCF-7 (FasR) and T47D (T47DfasR) cells continuously exposed to fulvestrant $\left(10^{-7} \mathrm{M}\right)$ for $>2$ years as previously described [35].

\section{Growth curves}

Cells were seeded overnight at 40,000 cells/well (24well plate) in their respective growth media. Cells were grown for seven days with $1 \mathrm{nM}$ to $1,000 \mathrm{nM}$ of the mTOR inhibitors AZD8055 or RAD001 (gifts from AstraZeneca) or appropriate vehicle control (dimethyl sulphoxide (DMSO)). Cell growth was evaluated by 
trypsin dispersion of cell monolayers and cell number was measured using a Coulter Counter. All TamR, MCF-7, MCF7-X, T47D-tamR and T47D-fasR experiments were performed at least in triplicate. In combination studies, fulvestrant was routinely used at 100 nM, a concentration shown previously to be growth inhibitory in TamR and MCF7-X models [2,3]. The growth impact of AZD8055 (0 to $100 \mathrm{nM}$ ) alongside oestrogen deprivation (using $\mathrm{X}$ cell medium as described above) or $10^{-7} \mathrm{M} 4-\mathrm{OH}$ tamoxifen was also evaluated in MCF-7 cells.

\section{Western blotting}

Cell lines were grown to $70 \%$ confluence in their respective media and then treated with a concentration range (1 $\mathrm{nM}$ to $100 \mathrm{nM}$ ) of AZD8055 or RAD001 for 15 minutes to 24 hours. Monolayers were washed with PBS and lysed in ice-cold lysis buffer (50 mM TRIS, $5 \mathrm{mM}$ ethylenediaminetetraacetic acid (EDTA), $150 \mathrm{mM}$ $\mathrm{NaCl}, 1 \%$ Triton-X100 $\mathrm{pH}$ 7.5) supplemented with protease and phosphatase inhibitors as previously described [4]. Lysates were clarified by centrifugation $(12,000 \mathrm{rpm}$, 15 minutes, $4^{\circ} \mathrm{C}$ ) and the protein concentration of the supernatant was determined. A total of $20 \mu \mathrm{g}$ protein was boiled for five minutes in SDS/dithiothreitol (DTT) sample buffer and resolved by SDS-PAGE. Proteins were transferred to nitrocellulose and after blocking for one hour in $5 \%$ skimmed milk (10 mM TRIS, $150 \mathrm{mM} \mathrm{NaCl}$, $0.05 \%$ Tween $20 \mathrm{pH}$ 7.6), they were incubated overnight with primary antibodies (1:1,000 dilution): mTOR (Cell Signalling Technology, Boston, Massachusetts, USA \#2972); P (ser2481) mTOR (Cell Signalling \#2974); $\mathrm{P}_{(\text {ser } 2448)}$ mTOR (Cell Signalling \#2971); Akt (Cell Signalling \#9272); P (ser 473) Akt (Cell Signalling \#9271); p70S6k (Cell Signalling \#9202);

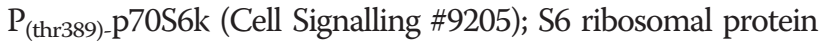
(Cell Signalling \#2217); P (ser235/236)-S6ribosomal protein (Cell Signalling \#2211); 4EBP-1 (Cell Signalling \#9644); P (thr37/46) 4E-BP-1 (Cell Signalling \#2855); P (thr246) PRAS40 (Cell Signalling \#2997); PRAS40 (Cell Signalling \#2610); $\mathrm{P}_{\text {-(thr202/tyr402) }}$ erk42/44 (Cell Signalling \#9101); p44/42 MAPK/erk1/2 (Cell Signalling \#9102); ER $\alpha$ (Santa Cruz Biotechnology, Dallas, Texas, USA sc543); $\mathrm{P}{ }_{(\text {ser167) }}$ ER (Upstate Merck Millipore, Billerica, Massachusetts, USA \#07-481); and P (ser118) ER (Santa Cruz 12915). Actin (Sigma \# A5441, at 1:50,000) was used as a loading control. Blots were washed with TBS/Tween and bound antibodies were detected after one hour incubation with horseradish peroxidase (HRP)-labelled secondary antibodies $(1: 10,000)$. Bound proteins were visualised by enhanced chemiluminescence (Pierce, Thermoscientific, Rockford, USA). Where appropriate, signal quantification was performed by densitometry (AlphaEase system) and normalised relative to actin.

\section{Polymerase Chain Reaction}

Total RNA was extracted from monolayers of cells treated for 72 hours with 0 to $100 \mathrm{nM}$ AZD8055 using TRIzol (Sigma) according to the manufacturer's instructions. Reverse transcription was performed on $1 \mu \mathrm{g}$ total RNA and PCR was performed as previously described [4]. Oligonucleotide primers were synthesised by Invitrogen and co-amplification was performed with $\beta$-actin used as a loading control. Samples treated with oestradiol or fulvestrant were used as a positive control to show ER-regulated modulation of target genes in MCF7-X and TamR cells $[3,36]$. PCR products were quantified by densitometry (AlphaEase) and normalised relative to actin. The following primers were used in this study:

\section{ß-Actin - GGA GCA ATG ATC TTG ATC T and CCT TCC TGG GCA TGG AGT CCT (202 bp) \\ Amphiregulin - TCC TCG GGA GCC GAC TAT GAC and GGA CTT TTC CCC ACA CCG (330 bp) pS2 - CAT GGA GAA CAA GGT GAT CTG and CAG AAG CGT GTC TGA GGT GTC (336 bp) cyclin D1-GCC TGT GAT GCT GGG CAC TTC ATC TG and TTT GGT TCG GCA GCT TGC TAG GTG AC (358 bp) \\ c-myc- TTG CAG CTG CTA GAC GCT G and CCA CAT ACA GTC CTG GAT GA (470 bp) bcl2- CAC CTG TGG TCC ACC TGA C and AGC CAG GAG AAA TCA AAC AGA G (376 bp)}

\section{Immunocytochemistry}

Subconfluent monolayers of TamR or MCF7-X cells were treated for one hour (phospho-ER $\alpha$ ) or 72 hours (Ki67, ER $\alpha, \mathrm{pS} 2)$ in their respective growth media in the presence of AZD8055 (1 to $100 \mathrm{nM}$ ) on 3aminopropyltriethoxysilane coated glass coverslips. Staining for the proliferation marker Ki67 (MIB1 antibody) was performed on cells fixed in 3.7\% formaldehyde/0.15 M $\mathrm{NaCl}$ for ten minutes, five minutes in $100 \%$ ethanol with a final wash in PBS before assay. Staining for phosphorylated ER $\alpha$ (ser167 or ser118 sites), pS2 and total ER $\alpha$ was performed on cells optimally-fixed for fifteen minutes with $3.7 \%$ formaldehyde in PBS, five minutes PBS, five minutes methanol $\left(-20^{\circ} \mathrm{C}\right)$, five minutes acetone $\left(-20^{\circ} \mathrm{C}\right)$ and five minutes PBS or with $2 \%$ paraformaldehyde with $20 \mathrm{mM}$ orthovanadate for twenty minutes followed by $2 \mathrm{x}$ five minutes PBS washes (ER $\alpha$ 118). Coverslips were blocked with $\mathrm{PBS} / 0.02 \%$ Tween for five minutes and incubated with 1:150 MIB1 (M7074 Dako Ltd, Ely, Cambridgeshire, UK) in PBS for one hour, or with 1:175 ER $\alpha$ (AB ER clone 6 F11 Vector Laboratories, Peterborough, UK) for 90 minutes; 1:100 ER 167 (Upstate \#07-481); 1:400 pS2 (Novocastra, Leica Biosystems, Newcastle-upon-Tyne, UK) for 90 minutes or 1:25 ER $\alpha 118$ (Cell Signalling \# 2515) overnight at room temperature. Unbound antibody 
was removed by washing with PBS. The EnVision (Dako) system was used for visualization (one to two hours at room temperature). Coverslips were washed in PBS and detected with diaminobenzidine tetrahydrochloride (DAB) and hydrogen peroxide chromogen substrate (Dako) and counterstained with methyl green. Immunostaining was evaluated at 20x magnification using an Olympus BH-2 light microscope and representative photographs were taken. For Ki67, estimates of percentage of cells deemed positive versus negative/equivocally-stained were determined from five fields of view for each coverslip (20x magnification) from three independent experiments.

\section{Sytox green viability assay}

A Sytox green viability assay was modified from Jones and Singer [37]. Cells were seeded into 96-cell plates $(5,000$ cells/well) and left to adhere overnight $\left(37^{\circ} \mathrm{C}, 5 \% \mathrm{CO}_{2}\right)$. After 24 hours (day 0), Sytox green, a cell impermeant green-fluorescent nucleic acid stain (Invitrogen), was added to each control well $(\mathrm{n}=8)$ (final concentration $1: 25,000)$ and after one hour the number of cells with a compromised plasma membrane (that is, late apoptotic and necrotic cells) that had taken up the sytox green was counted (number/well) using a fluorescent microscope. Cell membranes were permeabilised overnight with $0.25 \%$ saponin (Sigma) in the presence of sytox green, and then total cell number/well was counted. The remaining experimental cells were cultured for 72 hours in the presence of AZD8055 (0 to $100 \mathrm{nM}$ ), then the sytox green assay was performed to give a count for dead and total cell numbers as described above. Data were subsequently analysed by comparing live cell counts on day 0 with live cell counts on day 3. Cell death was considered to have occurred when the viable cell number fell below the day 0 pretreatment control number. Each treatment was assessed from eight replicates and three independent experiments.

\section{Migration assay}

Pore inserts $(8 \mu \mathrm{m}$, Costar \#3422) were incubated with $300 \mu \mathrm{l}$ sterile fibronectin (Sigma) in PBS $(10 \mu \mathrm{g} / \mathrm{ml})$ for two hours at $37^{\circ} \mathrm{C}$. Excess fibronectin was removed from the bottom of the insert by washing in PBS. Inserts were air dried for 15 minutes, then $650 \mu$ cell culture medium $+/-25 \mathrm{nM}$ AZD8055 was placed in the well and the insert suspended in it. A total of 40,000 TamR cells in normal growth medium were added to the insert and the plate was incubated for 24 hours at $37^{\circ} \mathrm{C}$. Cells on the insert were fixed with $3.7 \%$ formaldehyde (15 minutes). Cells on the inside of the insert were removed with a cotton swab and cells that had migrated to the lower side of the insert membrane were stained with $0.5 \%$ crystal violet for 30 minutes. Excess stain was removed by repeated washing with distilled water. Migrated cells were counted under an inverted light microscope over five fields of view (x20). Each experiment included triplicate wells and the experiment was repeated twice.

\section{Statistics}

Statistical analyses were carried out using a two sided t-test and ANOVA with post hoc test. $P<0.05$ was considered significant.

\section{Results}

Differential effects of RAD001 and AZD8055 on proliferation and signalling in acquired endocrine- resistant models

The allosteric mTOR inhibitor RAD001 (everolimus) was a relatively poor inhibitor of growth measured over seven days in MCF7-derived tamoxifen-resistant cells (TamR) with an $\mathrm{IC}_{50}$ of $950 \mathrm{nM}$. In long-term oestrogen deprived (MCF7-X) resistant MCF-7 cells, RAD001 was found to be even less potent $(P<0.05)$ with an $\mathrm{IC}_{50}>1 \mu \mathrm{M}$ (Figure $1 \mathrm{~A}$ ). In contrast, the mTOR kinase inhibitor AZD8055 at 10 to $100 \mathrm{nM}$ was a very effective inhibitor of growth in TamR cells $(P<0.001)$ with an $\mathrm{IC}_{50}$ of $18 \mathrm{nM}$. AZD8055 10 to 100 $\mathrm{nM}$ also substantially $(P<0.001)$ inhibited growth of the MCF7-X cell model, with an $\mathrm{IC}_{50}$ of $24 \mathrm{nM}$ (Figure 1B), although MCF7-X cells were significantly less sensitive than the TamR cells to AZD8055 when examined at $25 \mathrm{nM}(P=$ $0.035)$ and $50 \mathrm{nM}(P=0.019)$. Additional studies performed in a tamoxifen-resistant T47D-derived model (T47D-tamR) further confirmed that AZD8055 was highly growth inhibitory $\left(\mathrm{IC}_{50} 19 \mathrm{nM}\right)$ in acquired endocrine-resistant cells (Figure $1 \mathrm{C}$ ).

Despite having a poorer effect on cell growth, one hour treatment with RAD001 was still shown to inhibit mTORC1 (rapamycin sensitive) associated signalling pathways with TamR cells being slightly more sensitive to RAD001 than MCF7-X cells (Figure 1D). In both cell lines, RAD001 at $100 \mathrm{nM}$ caused a reduction in mTOR phosphorylation at s2448, which has previously been described as the site predominantly associated with the mTORC1 complex [38]. Downstream p70S6K phosphorylation in TamR was undetectable after treatment with $1 \mathrm{nM}$ RAD001 and pS6 activity was inhibited with RAD001 >10 nM. These mTORC1 downstream pathways were less sensitive to RAD001 in MCF7-X cells, but phosphorylation of p70S6K and pS6 were still inhibited by 100 nM RAD001. However, in both models, there was no impact of one hour treatment with RAD001 on pPRAS40. RAD001 was a poor inhibitor of mTORC2 (predominantly rapamycin-insensitive) pathways in both TamR and MCF7-X cells, indicated by its failure to significantly reduce both $\mathrm{s} 473$ Akt phosphorylation and mTOR phosphorylation at s2481, a site known to be associated with mTORC2 [38]. In both TamR and MCF7-X cells, RAD001 also failed to inhibit 4EBP-1 phosphorylation on the $\mathrm{t} 37 / 46$ site which has previously been described as rapamycin-insensitive [12]. 


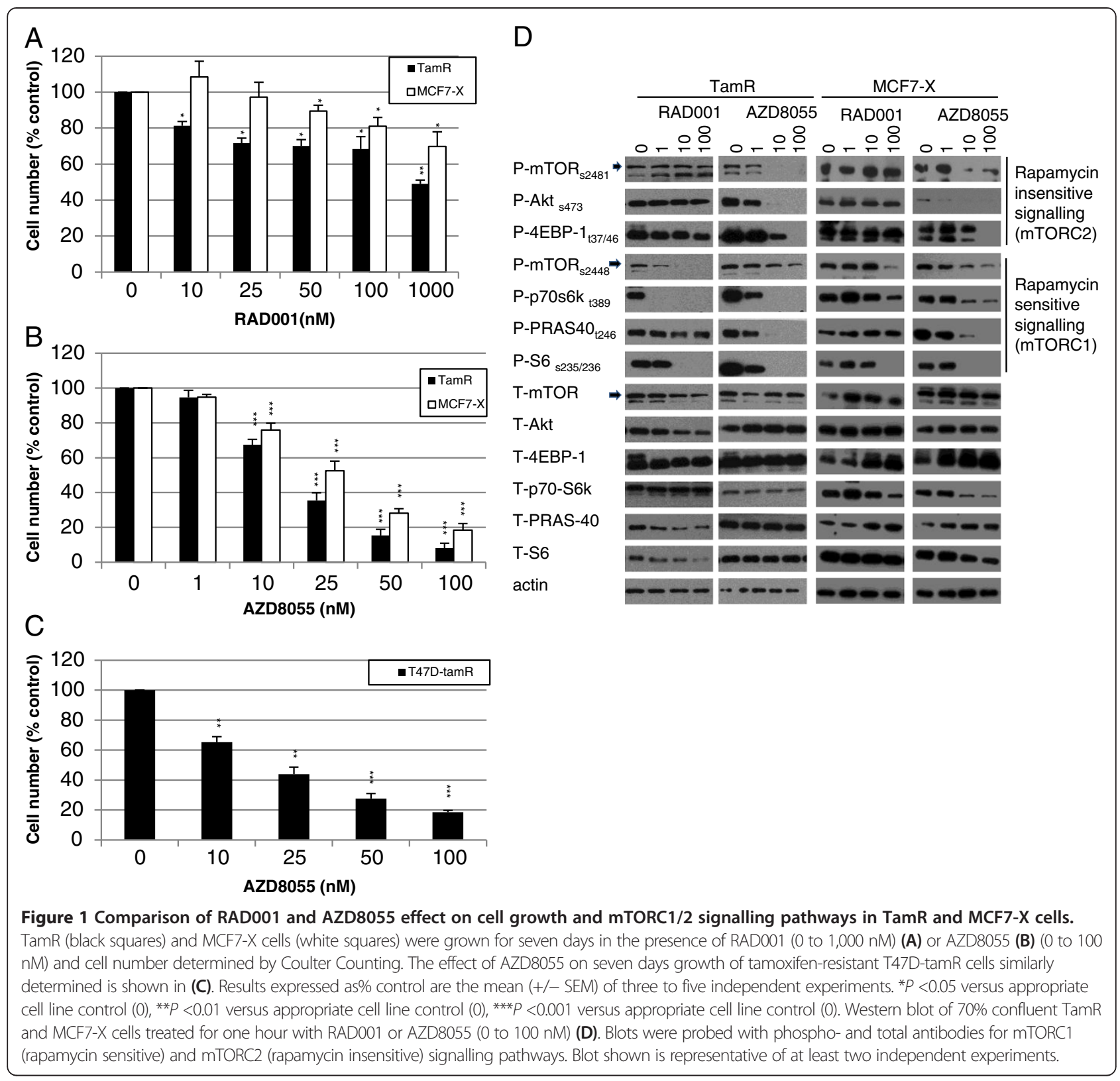

In contrast to RAD001, one hour treatment with AZD8055 inhibited pathways associated with both mTORC1 and mTORC2 signalling in both TamR and MCF7-X endocrine-resistant cell lines (Figure 1D). At concentrations from 1 to $100 \mathrm{nM}$, the inhibition of mTORC1 pathway elements, p-p70s6kinase and p-S6 ribosomal protein was similar or superior with AZD8055 to that seen with RAD0001. While inhibition of p-PRAS40 was not detected after one hour treatment with RAD001, PRAS40 phosphorylation was eliminated by $100 \mathrm{nM}$ AZD8055 in both TamR and MCF7-X cells. The biggest difference was seen with the mTORC2 associated signalling caused by AZD8055 with reduced activation of s2481 p-mTOR, complete inhibition of p-Akt by AZD8055 at 1 to $10 \mathrm{nM}$ and at concen- trations $>10 \mathrm{nM}$ complete inhibition of $4 \mathrm{EBP}-1$ at the rapamycin insensitive site t37/46. There was no consistent effect across replicate preparations on total protein expression over one hour treatment with either RAD001 or AZD8055.

\section{AZD8055 effect on mTORC1 and mTORC2 signalling in} TamR and MCF7-X cells is rapid and sustained

Since superior growth blockade and mTORC1/mTORC2 signalling inhibition was induced by AZD8055 in the endocrine resistant cancer cells, our subsequent detailed studies focused entirely on AZD8055. We investigated the sustainability of the AZD8055 signalling response and the inhibitory impact of AZD8055 on cell 
proliferation and survival in the TamR and MCF7-X resistant models.

Initial studies showed that within one hour AZD8055 (10 to $100 \mathrm{nM}$ ) inhibited both mTORC1 and mTORC2 signalling pathways similarly in both TamR and MCF7-X cells. Further studies were performed over a time course from 15 minutes through to 24 hours. Western blotting showed that mTORC1 and mTORC2 signalling in TamR and MCF7-X cells were both extremely sensitive to AZD8055 with 30 minutes treatment with $50 \mathrm{nM}$ AZD8055 demonstrating strong inhibition of mTOR at sites s2448 and s2481 in both resistant cells (Figure 2A-B). AZD8055 at a concentration of $10 \mathrm{nM}$ completely inhibited phosphorylation of Akt (s473), p70s6K (t389) and PRAS40 (t246) within 15 minutes. Reduction of phosphorylation of pS6 (s235/236) and 4EBP-1 (t37/ 46) was slightly slower, with complete inhibition being detected in TamR cells after 30 minutes of AZD8055 treatment, although p4EBP-1 was slightly less sensitive to inhibition in MCF7-X cells. The inhibitory effects of AZD8055 at $100 \mathrm{nM}$ were generally sustained throughout the time course, with the exception of p4EBP-1 and p-mTOR (s2448) in MCF7-X cells, although by 24 hours some recovery of signalling pathways (where expression returned to basal levels) was seen at the lower concentrations of AZD8055 examined. As expected, following 15 minutes to 48 hours treatment, we also observed that AZD8055 (10 to $100 \mathrm{nM}$ ) did not modulate the activation of $\mathrm{p}$-erk1/2 in both TamR and MCF7-X cells (Figure 2C).

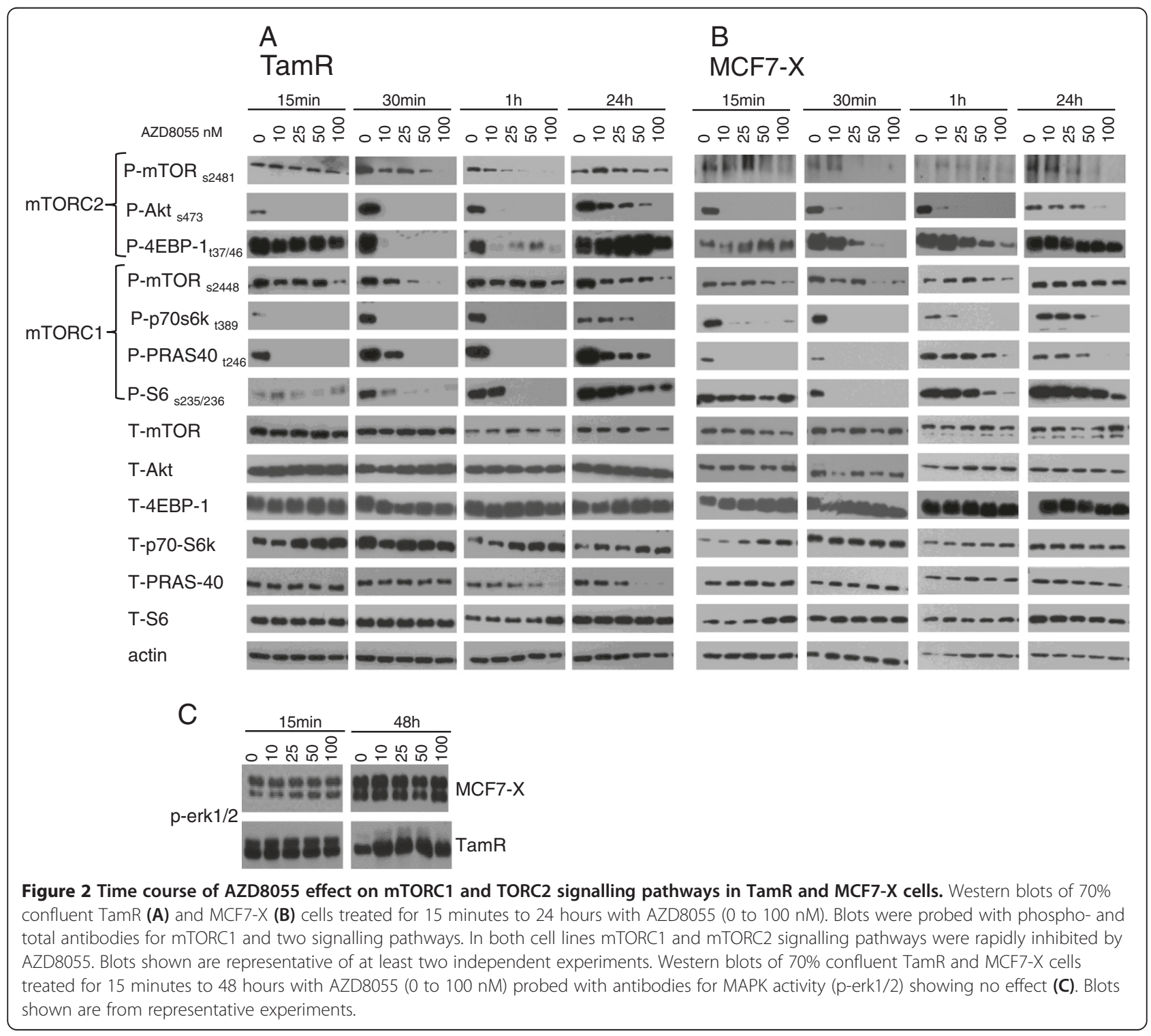



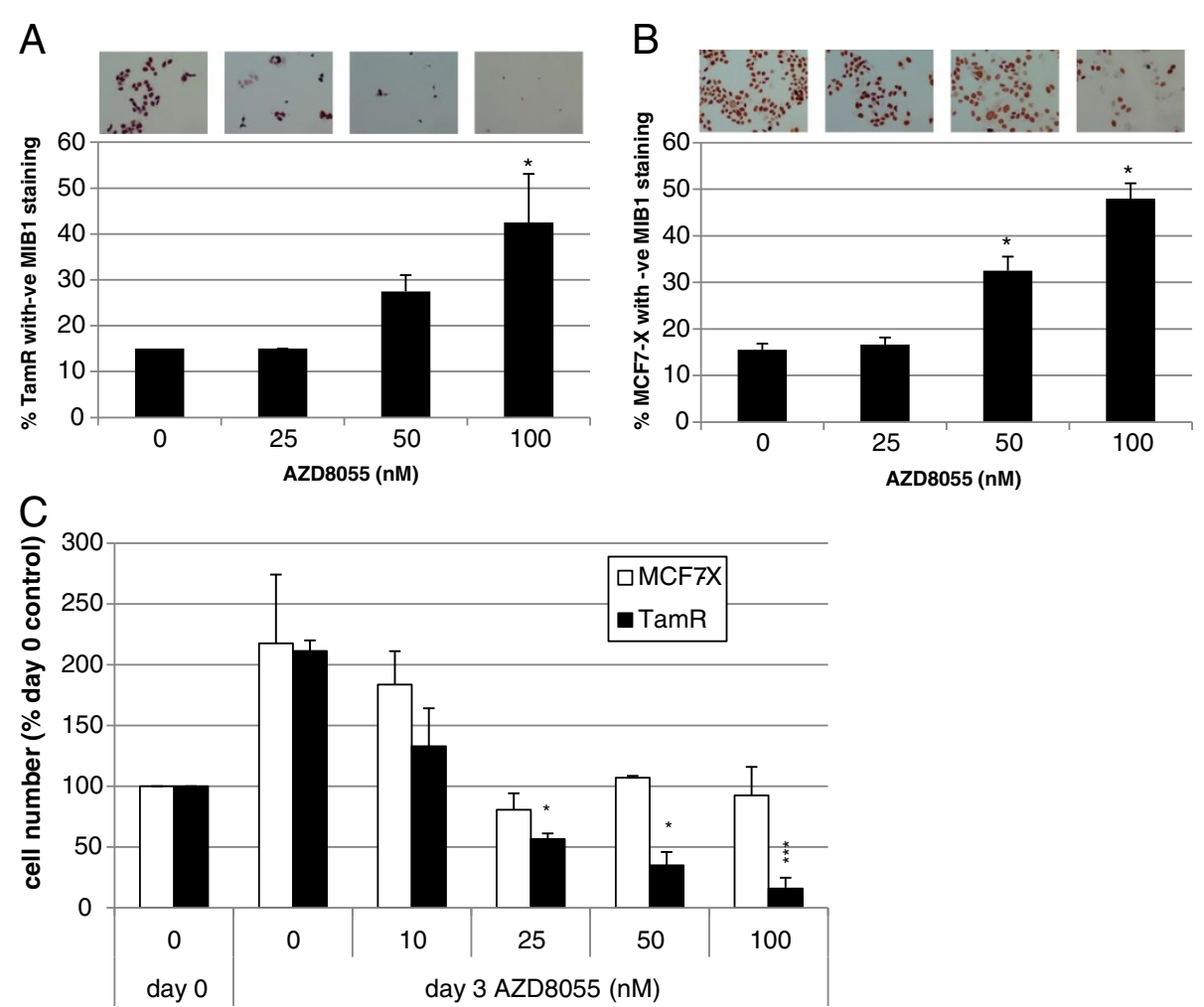

Figure 3 Effect of AZD8055 on proliferation and viability in TamR and MCF7-X cells. Immunocytochemical evaluation of MIB1 proliferation marker (Ki67) in TamR (A) and MCF7-X cells (B) treated for three days with AZD8055 (0 to $100 \mathrm{nM}$ ). Multiple fields of view ( $\times 20)$ were assessed for $\%$ cells expressing no/equivocal MIB1 staining. Results are from three independent experiments. ${ }^{*} P<0.05$ versus untreated control (ANOVA with post-hoc test). Sytox green impermeable nuclear stain was used to measure live cell count in TamR and MCF7-X cells in a viability cell assay before and after three days treatment with AZD8066 (C). After three days in the presence of 25 nM AZD8055, TamR live cell number fell below the pre-treatment count indicating some cell death with this agent. Live cell count (total minus dead cells) was a mean of eight replicates in three independent experiments. ${ }^{*} P<0.05,{ }^{* * *} P<0.001$ for three days treatment with AZD8055 versus appropriate day 0 control ANOVA with post-hoc test. ANOVA, analysis of variance.

Effect of AZD8055 on TamR and MCF7-X proliferation, cell survival and migratory behaviour

The impact of AZD8055 on TamR and MCF-7-X cell proliferation was monitored using MIB1 Ki67 staining. Three days treatment with $50 \mathrm{nM}$ AZD8055 reduced Ki67 staining in both TamR and MCF7-X cells and after treatment with $100 \mathrm{nM} 40 \%$ to $50 \%$ of all cells were deemed negative for MIB1 indicating a significant $(P<0.05)$ exit from the cell cycle (Figure 3A-B). These MIB1 results indicated that the dual $\mathrm{mTORC} 1 / 2$ inhibitor AZD8055 was acting to partially inhibit cell proliferation in TamR and MCF7-X cells. It was investigated whether cell death also contributed to reduced cell numbers in the presence of a concentration range of AZD8055. The sytox green viability assay showed that in TamR cells AZD8055 was not only cytostatic, but at concentrations $>25 \mathrm{nM}$, AZD8055 induced significant cell death with the TamR viable cell number falling to approximately $50 \%$ below the initial seeding number $(P<0.05)$. In contrast, in MCF7-X cells there was evidence from sytox green assays that while an anti-proliferative effect occurred this was without any significant cell death with AZD8055 when used as a single agent (Figure 3C). TamR cells (but not MCF7-X) have increased migratory ability compared to parental MCF-7 cells [39]. Although numbers of migrated TAMR cells were very modest, following 24 hours treatment with AZD8055 TamR migration was shown to be reduced by $40 \%$ showing that dual mTORC1/2 blockade has the capacity to impact on both resistant tumour cell growth and aggressiveness (Figure 4).

Investigation of any cross talk between ER and mTOR signalling targeted by AZD8055 in TamR and MCF7-X cells Both TamR and MCF7-X cells were derived from oestrogen-dependent MCF-7 breast cancer cells that have acquired tamoxifen or oestrogen deprivation resistance, respectively, but still grow in an ER $\alpha$ dependent manner [40]. In the TamR cell line, it is already known that there is prominent cross-talk between erk $1 / 2$ and 


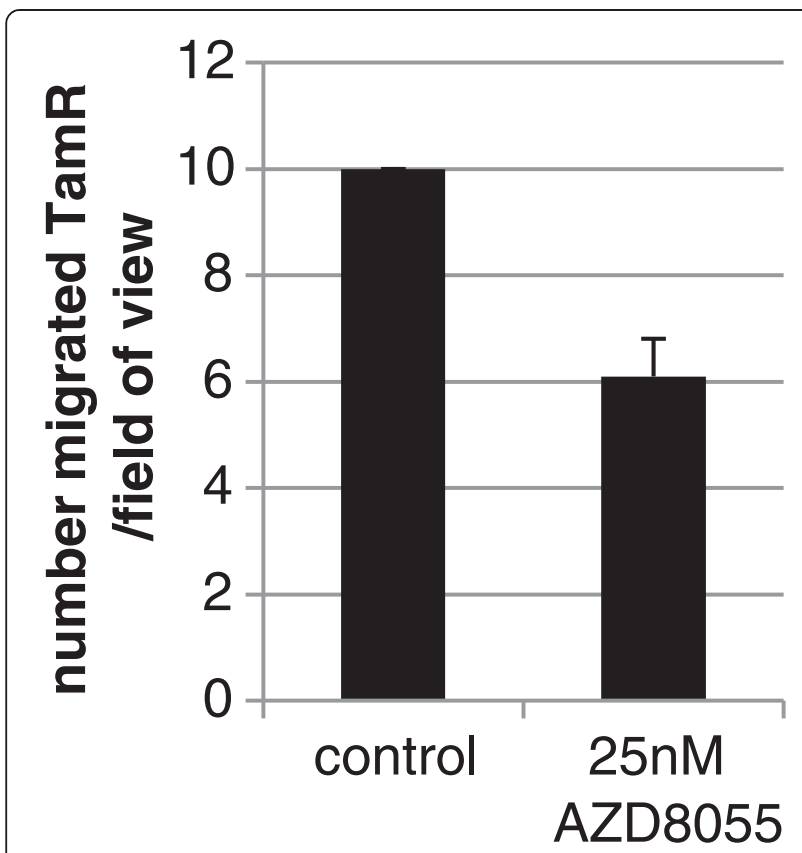

Figure 4 Effect of AZD8055 on migration in TamR cells. Twenty-four hours migration was measured over an $8 \mu \mathrm{m}$ pore membrane coated with fibronectin in the presence or absence of $25 \mathrm{nM}$ AZD8055. Results shown are from a representative experiment $(n=2)$.

phosphorylation of the ER s118 site in the ER AF-1 domain [36]. In MCF7-X cells, MAPK and PI3K/Akt also have the capacity to cross-talk with $E R$ at $\mathrm{pER}_{\text {ser118 }}$ and $\mathrm{pER}_{\mathrm{ser} 167}$, respectively [3]. Activation at such ER sites by cross-talk can contribute to driving transcription of oestrogen/ER regulated genes, notably amphiregulin which plays a part in the growth of TamR cells $[36,41]$ and also pS2 expression in MCF-7X cells [3]. The possible contribution of cross-talk between mTOR signalling and ER in these models of tamoxifen or oestrogen deprivation resistance was thus investigated using AZD8055 in the current study. Western blotting of MCF7-X and TamR confirmed prominent basal ER phosphorylation levels at ser118 and 167 in the latter model. Both models treated for one hour with AZD8055 (0 to $100 \mathrm{nM}$ ) showed, in conjunction with downregulation of mTOR activity at s2448 and s2481, a concentration dependent inhibition of ER phosphorylation at s167 (Figure 5A). Total ER and phosphorylation of ER at s118 were not significantly affected by AZD8055. Parallel immunocytochemistry (ICC) confirmed that nuclear $\mathrm{pER}_{\mathrm{ser167}}$, but not $\mathrm{pER}_{\mathrm{ser118}}$, in both MCF7-X and TamR cells was reduced after one hour exposure to $100 \mathrm{nM}$ AZD8055 (Figure 5B).

Potential interplay between mTOR blockade using AZD8055 and ER signalling was further investigated by PCR examination of the ER regulated gene $\mathrm{pS} 2$ as well as several ER-regulated genes more closely related to breast cancer cell growth: amphiregulin (important in TamR cells; [36], bcl2 (expressed in MCF7-X only), cmyc and cyclinD1. mRNA expression of these ER regulated genes was measured after 72 hours treatment with a concentration range of AZD8055 (1 to $100 \mathrm{nM}$ ) but failed to show any significant altered gene transcription in TamR or MCF7-X cells (Figure 6A-B). ICC in TamR and MCF7-X cells confirmed that 72 hours treatment with 1 to $100 \mathrm{nM}$ AZD8055 caused a concentration dependent reduction in cell number but did not alter expression of $\mathrm{pS} 2$ or ER protein in TamR or MCF7-X cells (Figure 6C). While only examining a limited panel of ER-regulated genes, these data do suggest that the mTOR inhibitor impact was independent of changes in ER-regulated transcriptional events and, hence, that mTOR and ER signalling are unlikely to be closely interactive in these acquired resistant models. The capacity for ER independent impact of AZD8055 was further supported by the demonstration that $25 \mathrm{nM}$ AZD8055 also inhibited growth by $60 \%\left(\mathrm{IC}_{50} 20 \mathrm{nM}\right)$ in an ER negative acquired fulvestrant-resistant cell line derived from MCF7 cells (FasR) (Figure 7A). This observation was also supported by AZD8055 growth studies in a T47D-derived ER- acquired fulvestrant-resistant line (T47D-fasR) with an $\mathrm{IC}_{50}$ of $18 \mathrm{nM}$ (Figure 7B).

AZD8055 and fulvestrant in combination enhance growth inhibition in TamR and MCF7-X cells

When ER positive breast tumours acquire resistance to an anti-hormone, an alternative anti-endocrine therapy can often be used successfully second-line, although resistance invariably emerges. In keeping with this, we have previously shown that the pure anti-oestrogen fulvestrant is growth-inhibitory in TamR [2] or MCF7-X cells in vitro [3], but growth inhibition is only partial, with the cells subsequently acquiring resistance to fulvestrant. We have investigated whether co-treating with a further anti-hormonal measure (fulvestrant) alongside an mTOR kinase inhibitor could offer an improved second-line treatment for endocrine-resistant cells versus either strategy alone. This was also important to evaluate since AZD8055 appears to be inhibitory independently of any substantial impact on ER-regulated events in our acquired endocrine resistant models. When TamR cells were treated for seven days with $25 \mathrm{nM}$ AZD8055 in combination with fulvestrant $(100 \mathrm{nM})$ there was a further $60 \%$ decrease in growth above that caused by fulvestrant $(P<0.001)$ and a $50 \%$ enhancement of growth inhibition compared to AZD8055 alone $(P<0.05)$ (Figure 8A). A similar improved anti-tumour effect was also observed in MCF-7X cells co-treated with AZD8055 and fulvestrant (Figure 8B) in which $25 \mathrm{nM}$ AZD8055 caused a further $60 \%$ decrease in growth above fulvestrant $(P<0.01)$ or AZD8055 alone $(P<0.05)$. These results 


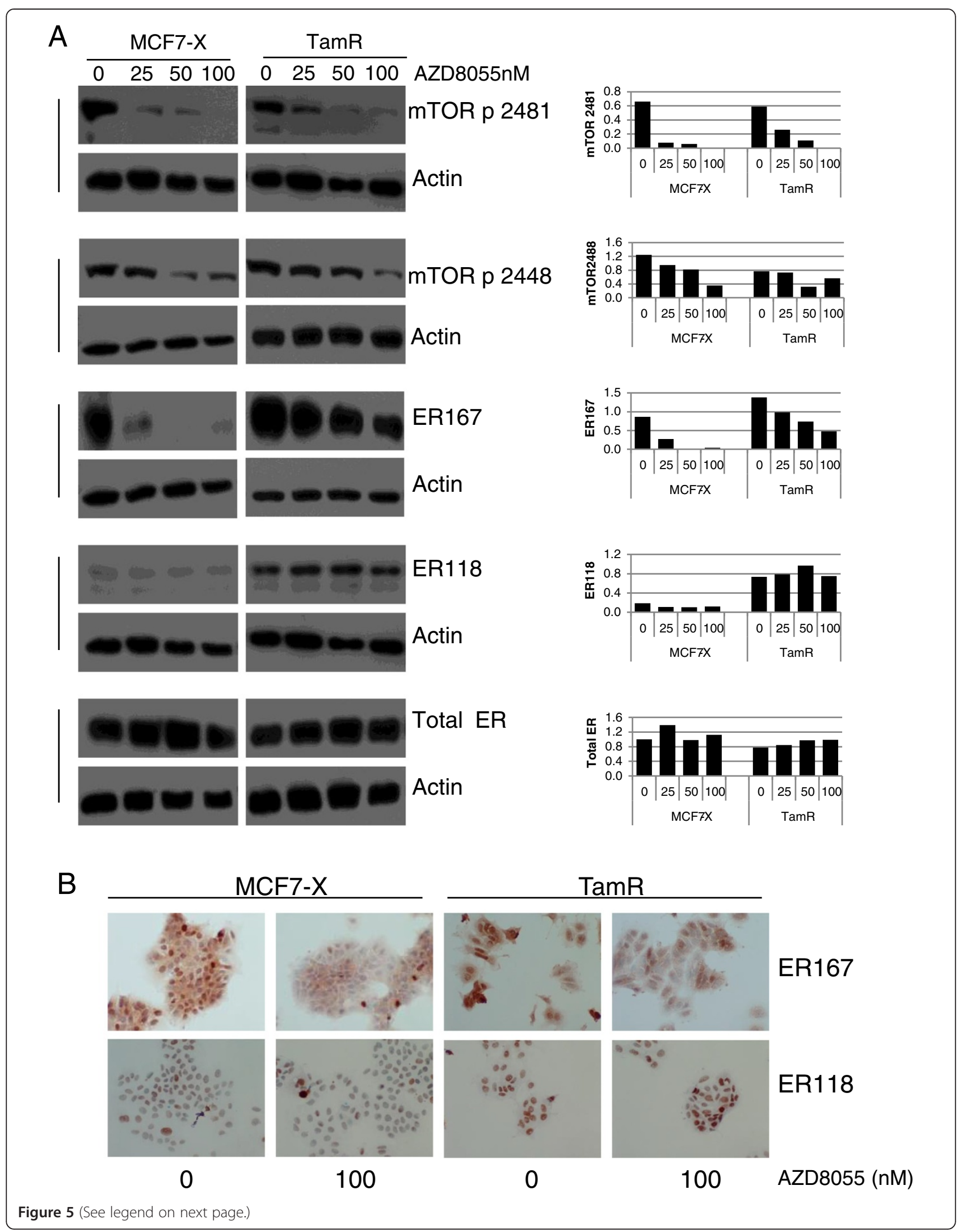


(See figure on previous page.)

Figure 5 One hour treatment with AZD8055 affects pER $_{\text {ser167 }}$ protein expression in TamR and MCF7-X cells. Western blot of 70\% confluent TamR and MCF7-X cells treated for one hour with AZD8055 (25 to $100 \mathrm{nM}$ ). Images show blots probed for pER (s118 and s167), total ER, mTOR phosphorylation on s 2481 and s2448 to demonstrate mTOR inhibition and actin to indicate equal loading. The accompanying bar charts show densitometric analysis of western blot data normalised to actin. $p E R_{\text {ser167 }}$ but not $p E R_{\text {ser1 } 18}$ protein was inhibited in MCF7-X and TamR cells. Blots are representative of two independent experiments (A). Accompanying immunocytochemical images confirm the effect of AZD8055 on pER $R_{\text {ser167 }}$ but not $p E R_{\text {ser118 }}$ protein expression in TamR and MCF7-X cells. Immunocytochemistry was performed on TamR and MCF7-X cells fixed after treatment +/- AZD8055 (100 nM) for one hour and cells were stained with antibodies for pER $\mathrm{R}_{\text {ser1 } 18}$ and pER $\mathrm{R}_{\text {ser167 }}$ (B). At least five fields of view were examined for staining and representative images (x20) shown. Results are shown from at least three independent experiments.

suggest that an mTOR kinase inhibitor (exemplified here by AZD8055) plus anti-oestrogen fulvestrant combination could have potential as a superior second-line treatment for endocrine resistant breast cancers that do not respond well to the rapalogue everolimus.

Finally, while seven day treatment with AZD8055 was also a good inhibitor of growth in anti-oestrogen sensitive MCF-7 parental cells with an $\mathrm{IC}_{50}$ of $12 \mathrm{nM}$ (Figure 9), a superior growth inhibition could again be obtained by co-treatment with AZD8055 and either 4-OH-tamoxifen $\left(10^{-7} \mathrm{M}\right)$ or severe oestrogen deprivation (X medium containing charcoal stripped and heat treated FCS). The anti-tumour effect was increased by $66 \%(P<0.01)$ and 56\% $(P<0.05)$, respectively, by combination with 10 nM AZD8055 versus the anti-hormone treatment alone (Figure 9). These findings suggest that in combination with anti-hormone therapy, mTOR kinase blockade could also provide a first-line treatment strategy to inhibit endocrine responsive disease more effectively and thereby hinder acquisition of resistance in breast cancer.

\section{Discussion}

Endocrine resistant breast cancer and clinical status of mTOR targeting with rapalogue RAD001

Acquisition of resistance to endocrine therapy remains a major problem in the treatment of ER + breast cancer

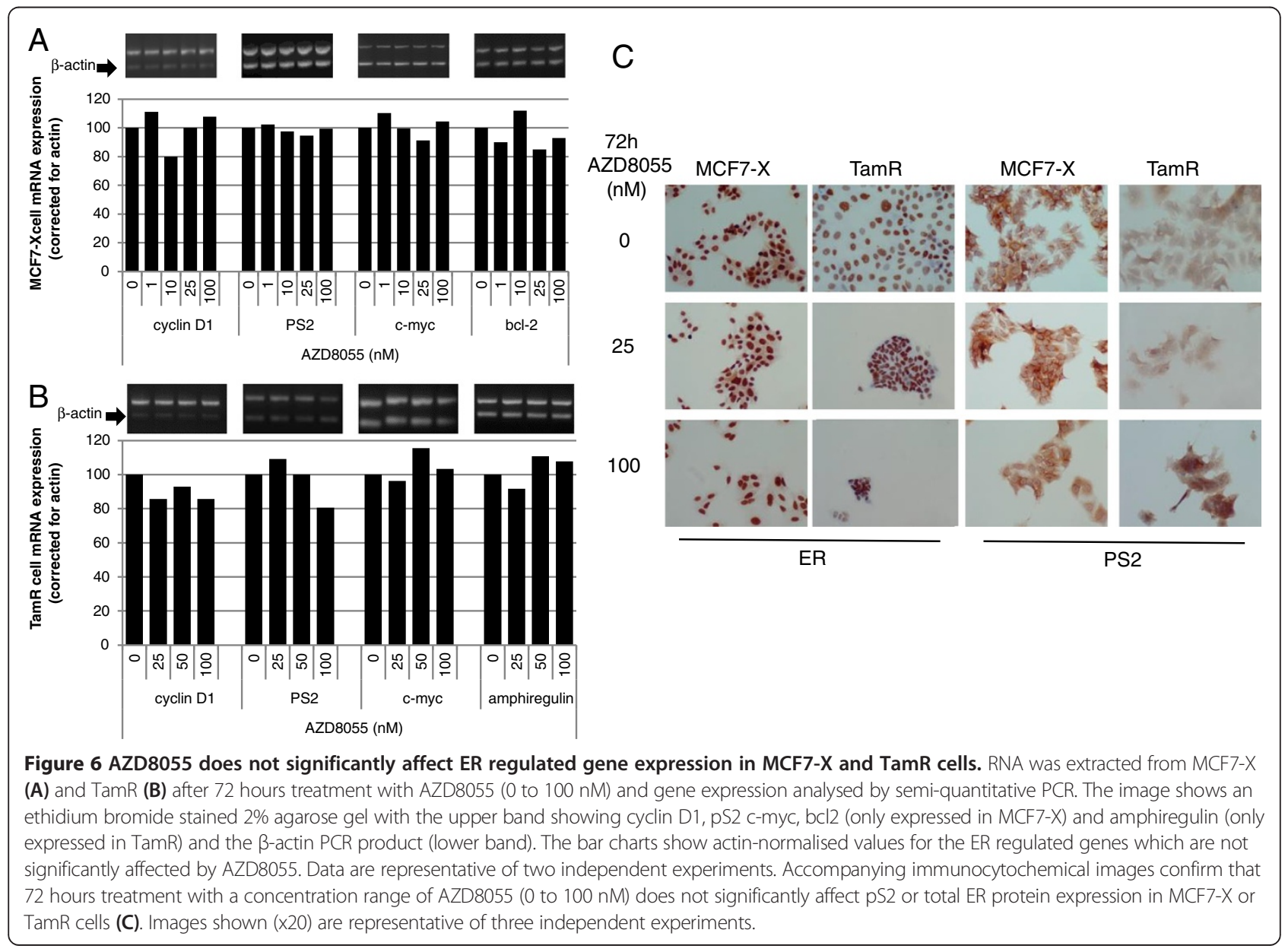




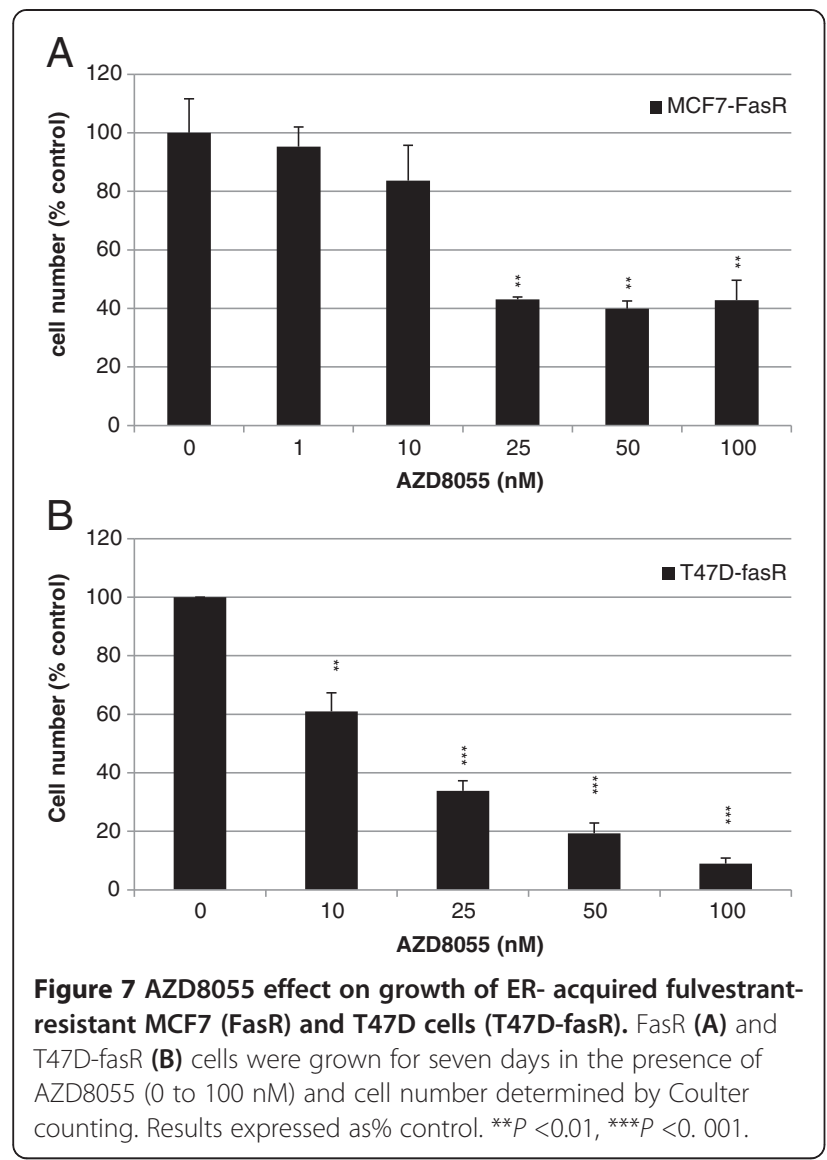

and using inhibitors to target de-regulated growth factor signalling pathways, such as mTOR, has become an important therapeutic approach currently under intense clinical evaluation. Initial preclinical studies demonstrated that tamoxifen resistance is mediated in part by mTOR signalling [42]. This contributed towards the rationale for successful clinical studies where rapalogue treatment was combined with aromatase inhibitor (BOLERO-2) or tamoxifen (TAMRAD) therapy $[26,27,43,44]$ which resulted in approval of the rapalogue everolimus (Afinitor, RAD001), in combination with the steroidal aromatase inhibitor exemestane (Aromasin), for treatment of post-menopausal women with advanced ER+/HER2breast cancer progressing on a non-steroidal aromatase inhibitor. Critically, however, although the BOLERO-2 trial showed that the objective response rate was improved for everolimus/antihormone combination versus antihormone alone, no patients showed complete response and some patients remained refractory to this rapalogue therapy or developed resistance during treatment [26]. The signalling pathways that limit the impact of rapalogues in endocrine resistant breast cancer have to date been largely undefined. Here, we have studied the use of the mTOR kinase inhibitor AZD8055 as a potential

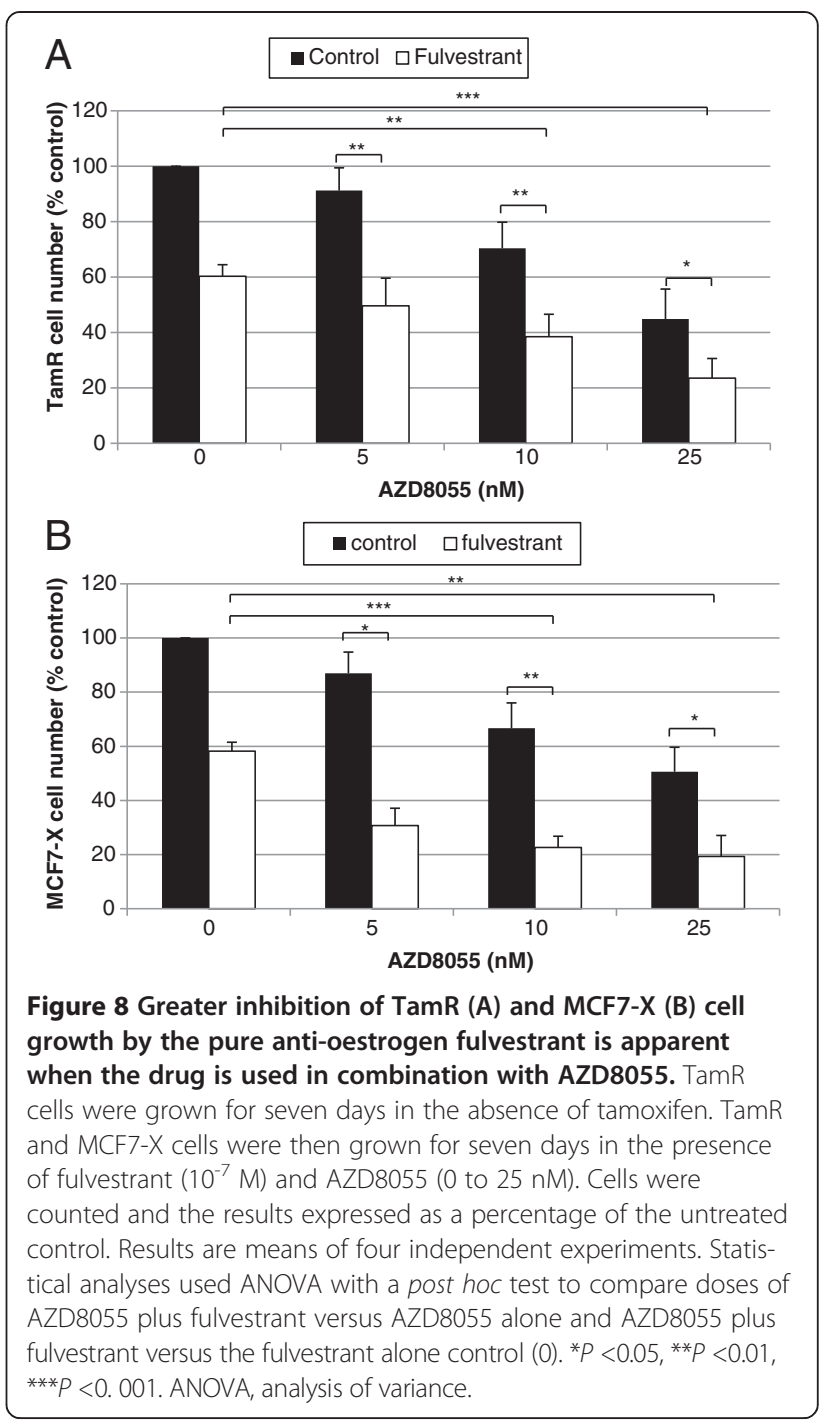

treatment for acquired endocrine-resistant breast cancers including those refractory to rapalogue treatment.

Importance of mTORC2/AKT signalling in acquired endocrine resistant models resistant to rapalogue RAD001

Our study has predominantly focussed on MCF7-X and TamR cells as in vitro models that aim to represent clinical relapse after first line oestrogen deprivation or tamoxifen treatment, respectively [2,3]. Interestingly, we found that MCF7-X cell growth was completely, and TamR cells partially, resistant to inhibition by RAD001 (everolimus, $\mathrm{IC}_{50} \geq 1 \mathrm{uM}$ ), despite inhibition of target TORC1 signalling $\left(\mathrm{mTORC}_{\mathrm{ser} 2448}, \mathrm{p} 70 \mathrm{S6} \mathrm{k}\right.$ and $\mathrm{pS6}$ ). Similar growth and signalling effects have been reported by others in MCF-7 cells with acquired tamoxifenresistance [45]. Critically, in our study RAD001 failed to inhibit the mTORC2 signalling complex which is a major regulator of Akt activity [46]. Thus, p$\mathrm{mTOR}_{\text {ser2481 }}$ (mTORC2), p-Akt $\mathrm{Aer}_{\mathrm{s} 43}$ and also growth, 


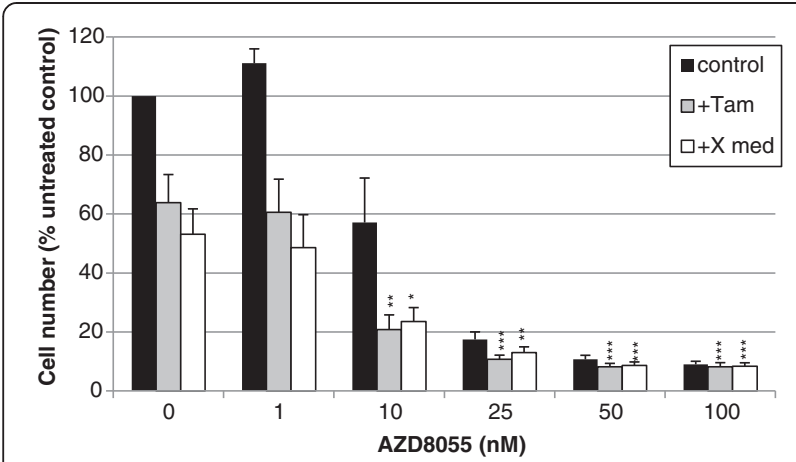

Figure 9 Greater inhibition of MCF-7 cell growth is apparent when AZD8055 is used in combination with tamoxifen or oestrogen deprivation. Seven days growth of oestrogen

dependent MCF-7 cells was compared in standard control medium (black squares), in the presence of $10^{-7} \mathrm{M}$ tamoxifen (grey square) or oestrogen-deprived medium (X cell medium) (white squares) with a concentration range of AZD8055 (0 to $100 \mathrm{nM}$ ). Triplicate wells of cells were counted by Coulter Counter and the results expressed as a percentage of the untreated control cells. Combination with 10 nM AZD8055 significantly increased growth inhibition in the presence of tamoxifen or oestrogen-deprived medium by $66 \%$ and $56 \%$, respectively, versus anti-hormone alone. ${ }^{*} P<0.05,{ }^{* *} P<0.01$, ${ }^{* * *} P<0.001$ versus appropriate anti-hormone control in the absence of AZD8055 (0). Results shown are means of three independent experiments. Statistical analysis was performed with ANOVA and post hoc test. ANOVA, analysis of variance.

which is in part AKT-driven in TamR and MCF7-X cells $[3,4]$, were not inhibited by this agent. Reports of rapamycin-sensitivity in long-term oestrogen deprived (LTED) MCF-7 cells from other groups [45,47-50] have ranged from being modest [48] to very sensitive [49], with increased HER2 expression invariably reported to be a predictor for their increased RAD001 sensitivity $[45,49]$. Oestrogen deprivation-resistant MCF7-X cells differ in that they do not have up-regulation of HER2 (or IGF1R) [3], and indeed such growth factor receptors only rarely increase in clinical endocrine relapse samples [51]. It is thus probable that some dependence on the PI3K/Akt pathway in MCF7-X cells coupled with only low HER2 activity cumulatively results in their prominent growthinsensitivity to RAD001.

\section{Rapalogue insensitive acquired endocrine resistant cells retain sensitivity to $\mathrm{mTOR}$ kinase inhibition}

Given their substantial RAD001 growth insensitivity, TamR and MCF7-X cells could comprise useful models to understand everolimus resistance in tamoxifen or oestrogen deprivation-resistant patients and to determine improved treatments. In this regard, our findings suggest that inhibition of both TORC2/Akt and TORC1 may be critical. We have shown that growth of cancer cells unresponsive to an allosteric mTOR inhibitor can still be sensitive to mTOR kinase blockade, with AZD8055 substantially inhibiting growth in TamR and MCF7-X cells ( $\mathrm{IC}_{50} 18$ and $24 \mathrm{nM}$, respectively). To the best of our knowledge, this is the first report suggesting the potential for $\mathrm{mTOR}$ kinase inhibitors in rapalogue-(RAD001) insensitive ER+/HER2- breast cancer cells with acquired endocrine resistance. Clearly, it should be remembered that there are limitations to studies based on homogeneous cell cultures because such modelling cannot reflect the breadth of clinical heterogeneity of $\mathrm{ER}+$ disease or microenvironment impact $[52,53]$. However, experimental work has shown that resistant cell lines can reflect features seen in some clinical breast cancer samples $[54,55]$ and our additional results here are encouraging in that they show AZD8055 is also highly growthinhibitory in a further ER + acquired endocrine-resistant model, T47D-tamR ( $\left.\mathrm{IC}_{50} 19 \mathrm{nM}\right)$.

Our TamR and MCF7-X signalling studies indicate that the difference in the mechanism of action of these drugs enables AZD8055 to target mTORC2 signalling in addition to mTORC1; thus, basal p-Akt ser 473 is rapidly and substantially inhibited by AZD 8055 in both models but is unaffected by RAD001. Furthermore, inhibition of a negative feedback loop downstream of mTORC1 $[22,24]$ can result in induction of Akt activity in patients treated with everolimus [18]. This event may limit the effectiveness of mTORC1-targeting therapy since it can be associated with shortened time to progression in patients [56,57]. However, in both TamR and MCF7-X cells, basal Akt ser473 inhibition by AZD8055 was sustained with no up-regulation over 24 hours treatment. A similar response to AZD8055 has been reported in further breast cancer cell lines [12], while clinically a close analogue of AZD8055, AZD2014, also inhibits pAKT, pS6 and p4EBP-1 in some tumours [58].

AZD8055 has previously been reported to induce cell death and autophagy in lung and leukaemia cancer cells [59-61], contrasting rapalogues that are often poor inducers of cell death $[12,59]$. In the present study, some cell death was induced in TamR but not in MCF7-X cells by AZD8055. Since bcl-2 mRNA was detected basally in MCF7-X, but not in TamR cells, this anti-apoptotic factor may contribute towards the somewhat-reduced AZD8055sensitivity in MCF7-X versus TamR cells. Interestingly, rapamycin-resistant tumours have previously been reported to express high levels of bcl-2 [62,63]. The increased effectiveness of AZD8055 over RAD001 in TamR and MCF7-X cells may also relate to the reported ability of mTOR kinase inhibitors to deplete overall protein synthesis more strongly than rapamycin [64], where inhibition of 4E-BP1 phosphorylation at rapamycin resistant sites t37 and 46 [12] with AZD8055 may increase inhibition of cap-dependent translation [61,65]. Interestingly, AZD8055 showed a superior impact on 4E-BP1 phosphorylation in TamR versus MCF7-X cells, which may contribute towards increased AZD8055 sensitivity in the former model. 


\section{Sensitivity to mTOR kinase inhibitor can occur} independently of ER in acquired endocrine resistant cells Clinically, acquired endocrine-resistant tumours often respond to second-line antihormonal therapy and TamR and MCF7-X cells similarly retain ER dependency, responding to fulvestrant challenge $[2,3]$. In endocrineresistant cancers, nuclear ER activity can be driven in a ligand-independent manner via cross-talk with growth factor protein kinase cascades including MAPK and PI3K/ Akt with emerging evidence for a role of mTOR [43]. Thus, rapalogue treatment has been reported to inhibit pER $_{\text {ser167 }}$ in LTED MCF-7 cells and in a tamoxifen and fulvestrant-resistant MCF-7-derived line R-MVLN [49,66], while S6kinase (S6K), a downstream TORC1 target, is also able to phosphorylate a consensus motif at $\mathrm{pER}_{\mathrm{ser} 167}$ $[67,68]$. Although our results have also provided some support of cross-talk via ER phosphorylation in MCF7-X and TamR cells, where $p E R_{\text {ser167 }}$ was rapidly inhibited by the mTOR kinase inhibitor AZD8055, extensive PCR investigation failed to demonstrate any significant inhibitory effect of AZD8055 on ER-regulated gene transcription. We have also been unable to show a convincing impact of AZD8055 on basal or oestradiol-stimulated oestrogen response element activity in MCF7-X and TamR using reporter gene construct studies (data not shown). The contribution of ER phosphorylation at individual sites is generally underexplored, although phosphorylation of either ser ${ }^{167}$ or ser ${ }^{118}$ in the AF1 domain of ER $\alpha$ can exert only a small effect on gene transcription [69]; hence, the significance of ER ${ }_{\text {ser167 }}$ inhibition with AZD8055 in TamR and MCF7-X cells remains unclear. Significantly, in TamR cells, EGFR/MAPK signalling is a predominant driver of $\mathrm{pER}_{\text {ser118 }}$ [36] and MAPK also has some capacity in maintaining $\mathrm{pER}_{\text {ser118 }}$ activity in MCF7-X cells [3]. The observation that activity of both $\mathrm{pER}_{\text {ser118 }}$ and MAPK were refractory to AZD8055 may thus explain the apparent inability of the drug to impact on genomic ER function in these endocrine-resistant cells. Clearly, AZD8055 appears able to promote its growth inhibitory effects in an ER independent manner in TamR and MCF7-X cells, an outcome supported by the observation that it retains substantial growth-inhibitory activity in two acquired fulvestrantresistant cell lines that have lost all ER expression (MCF-7-derived FasR and also T47D-fasR) [35]. Interestingly, rapalogues have also been shown to have favourable activity in triple-negative breast cancer cells [70].

\section{Superior impact of mTOR kinase inhibitor alongside further ER blockade (fulvestrant) in acquired endocrine resistant models}

We have previously shown that although ER remains an important growth contributor in TamR and MCF7-X cells, fulvestrant responses are incomplete in these models and resistance subsequently emerges during treatment [2,3,36]. This finding mirrors relapse during second line endocrine treatment that occurs in many patients. Reports in various cell lines have shown that co-treatment with everolimus and endocrine therapy can exert additive or synergistic growth inhibitory effects $[42,43,71,72]$. Importantly, AZD8055 significantly improved the anti-tumour effect of fulvestrant in both TamR and MCF7-X cells, suggesting that such combination treatment might prove valuable in breast cancer after initial endocrine failure. Moreover, since our TamR and MCF7-X models were also RAD001 refractory, it is feasible that the value of such combination therapy might extend to patients who are refractory to combined treatment with everolimus plus exemestane or tamoxifen [26,27]. Our preclinical findings are promising given that trials are ongoing in advanced breast cancer patients using fulvestrant in combination with the mTOR kinase inhibitor AZD2014 (ClinicalTrials.gov: NCT01597388). Finally, it is noteworthy that in the parental MCF-7 line, we also observed a greater anti-tumour effect with AZD8055 alongside tamoxifen or oestrogen-deprivation. As such, co-treatment may additionally have some capacity to hinder development of resistance. The efficacy of everolimus alongside endocrine agents in the adjuvant setting is currently being explored in ER+/HER2- patients at high risk of relapse (ClinicalTrials.gov: UNIRAD), and based on our preclinical findings here, evaluation of early combination treatment using an mTOR kinase inhibitor may be equally worthy of exploration where it may help to delay or prevent acquisition of endocrine resistance.

\section{Conclusions}

Our findings using endocrine-resistant breast cancer cell lines demonstrate for the first time that dual targeting of mTORC1 and mTORC2/AKT signalling with an mTOR kinase inhibitor (AZD8055) can be effective even under conditions in which the allosteric mTORC1 inhibitor RAD001 (everolimus) fails to control growth. Moreover, combined treatment with AZD8055 alongside antihormones provides a particularly potent growth inhibitory strategy both for the TamR and MCF7-X models and for endocrine responsive MCF-7 cells.

\section{Abbreviations}

4E-BP1: eukaryotic translational initiation factor 4E binding protein 1; ANOVA: analysis of variance; BC: breast cancer; bp: base pair; DMSO: dimethyl sulphoxide; EGFR: epidermal growth factor receptor; ER: oestrogen receptor; FCS: foetal calf serum; HER2/erbB2: human epidermal growth factor receptor-2; ICC: immunocytochemistry; IGF-1R: insulin-like growth factor receptor 1; LTED: long-term oestrogen deprived; MAPK: mitogen activated protein kinase.; mTOR: mammalian target of rapamycin; p70S6K: p70 ribosomal S6 kinase, S6K S6 kinase; PBS: phosphate-buffered saline; PCR: polymerase chain reaction; PI3K: phosphtidylinositol-3 kinase; RAD001: everolimus/Afinitor; RAPTOR: regulatory associated protein of mTOR; RICTOR: RAPTOR independent rapamycin insensitive companion of mTOR; sFCS: charcoal stripped FCS; SGK1: serum and glucocorticoid regulated kinase 1, rapalogue rapamycin analogue. 


\section{Competing interests}

JMWG, RIN and IRH are in receipt of research funding from AstraZeneca. SMG is an employee of AstraZeneca. NJJ and the work included in this study was predominantly research funded by AstraZeneca. The remaining authors have no conflict of interest.

\section{Authors' contributions}

As Principal Investigator, JMWG conceived the study, participated in its design and execution and helped to draft and provide critical revision of the manuscript. RIH, RIN and SMG participated in the design of the study and provided further critical revision of the manuscript. NJJ drafted the manuscript, designed the experiments and carried out cell culture, Western blotting, ICC, proliferation, viability assays and PCR and interpreted the data. CMD, HJM and DB designed and carried out growth studies, analysed and interpreted this data. HJM also carried out migration assays. All authors read and approved the final manuscript.

\section{Acknowledgements}

The authors thank Lynne Farrow for performing the statistical analyses, Susan R Kyme for expert ICC assistance and Lindy Goddard and Richard A McClelland for carrying out pilot laboratory studies that led to this research project. This research was supported by funding from AstraZeneca (NJJ, LG, RAM) and the Breast Cancer Campaign (JMWG), Experimental Cancer Medicine Centre (ECMC) at Cardiff University (HJM), the In The Pink Breast Cancer Charity (SRK), and Cardiff University (DB, CMD, LF).

\section{Author details}

'Breast Cancer (Molecular Pharmacology) Group, Cardiff School of Pharmacy and Pharmaceutical Sciences, Cardiff University, Redwood Building, King Edward VII Avenue, Cardiff CF10 3NB, UK. ${ }^{2}$ Department of Pharmacology, Therapeutics \& Toxicology, Cardiff University School of Medicine, UHW Main Building, Heath Park, Cardiff CF14 4XN, UK. ${ }^{3}$ Oncology, AstraZeneca, Alderley Park, Macclesfield, Cheshire SK10 4TG, UK. ${ }^{4}$ CUPUCI, School of Medicine, Cardiff University, Henry Wellcome Building, Heath Park, Cardiff CF14 4XN, UK.

Received: 21 June 2013 Accepted: 15 January 2014

Published: 23 January 2014

\section{References}

1. Osborne CK, Schiff R: Mechanisms of endocrine resistance in breast cancer. Annu Rev Med 2011, 62:233-247.

2. Hutcheson IR, Knowlden JM, Madden TA, Barrow D, Gee JM, Wakeling AE, Nicholson Rl: Oestrogen receptor-mediated modulation of the EGFR/ MAPK pathway in tamoxifen-resistant MCF-7 cells. Breast Cancer Res Treat 2003, 81:81-93.

3. Staka CM, Nicholson Rl, Gee JM: Acquired resistance to oestrogen deprivation: role for growth factor signalling kinases/oestrogen receptor cross-talk revealed in new MCF-7X model. Endocr Relat Cancer 2005, 12:S85-597.

4. Jordan NJ, Gee JM, Barrow D, Wakeling AE, Nicholson RI: Increased constitutive activity of PKB/Akt in tamoxifen resistant breast cancer MCF-7 cells. Breast Cancer Res Treat 2004, 87:167-180.

5. Martin LA, Ghazoui Z, Weigel MT, Pancholi S, Dunbier A, Johnston S, Dowsett $\mathrm{M}:$ An in vitro model showing adaptation to long-term oestrogen deprivation highlights the clinical potential for targeting kinase pathways in combination with aromatase inhibition. Steroids 2011, 76:772-776.

6. Zhou X, Tan M, Stone Hawthorne V, Klos KS, Lan KH, Yang Y, Yang W, Smith TL, Shi D, Yu D: Activation of the Akt/mammalian target of rapamycin/4E-BP1 pathway by ErbB2 overexpression predicts tumor progression in breast cancers. Clin Cancer Res 2004, 10:6779-6788.

7. Zagouri F, Sergentanis TN, Chrysikos D, Filipits M, Bartsch R: mTOR inhibitors in breast cancer: a systematic review. Gynecol Oncol 2012. 127:662-672.

8. Laplante M, Sabatini DM: mTOR signaling at a glance. J Cell Sci 2009, 122:3589-3594.

9. Choi J, Chen J, Schreiber SL, Clardy J: Structure of the FKBP12-rapamycin complex interacting with the binding domain of human FRAP. Science 1996, 273:239-242

10. Richter JD, Sonenberg N: Regulation of cap-dependent translation by elF4E inhibitory proteins. Nature 2005, 433:477-480.
11. Jacinto E, Loewith $R$, Schmidt A, Lin S, Ruegg MA, Hall A, Hall MN: Mammalian TOR complex 2 controls the actin cytoskeleton and is rapamycin insensitive. Nat Cell Biol 2004, 6:1122-1128.

12. Rodrik-Outmezguine VS, Chandarlapaty S, Pagano NC, Poulikakos PI, Scaltriti M, Moskatel E, Baselga J, Guichard S, Rosen N: mTOR kinase inhibition causes feedback-dependent biphasic regulation of AKT signaling. Cancer Discov 2011, 1:248-259.

13. Sarbassov DD, Ali SM, Sengupta S, Sheen JH, Hsu PP, Bagley AF, Markhard AL, Sabatini DM: Prolonged rapamycin treatment inhibits mTORC2 assembly and Akt/PKB. Mol Cell 2006, 22:159-168.

14. Markman B, Dienstmann R, Tabernero J: Targeting the PI3K/Akt/mTOR pathway-beyond rapalogs. Oncotarget 2010, 1:530-543.

15. Mita MM, Mita A, Rowinsky EK: Mammalian target of rapamycin: a new molecular target for breast cancer. Clin Breast Cancer 2003, 4:126-137.

16. Chan S, Scheulen ME, Johnston S, Mross K, Cardoso F, Dittrich C, Eiermann W, Hess D, Morant R, Semiglazov V, Borner M, Salzberg M, Ostapenko V, Illiger HJ, Behringer D, Bardy-Bouxin N, Boni J, Kong S, Cincotta M, Moore L: Phase II study of temsirolimus (CCl-779), a novel inhibitor of mTOR, in heavily pretreated patients with locally advanced or metastatic breast cancer. J Clin Oncol 2005, 23:5314-5322.

17. Raymond E, Alexandre J, Faivre S, Vera K, Materman E, Boni J, Leister C, Korth-Bradley J, Hanauske A, Armand JP: Safety and pharmacokinetics of escalated doses of weekly intravenous infusion of $\mathrm{CCl}-779$, a novel mTOR inhibitor, in patients with cancer. J Clin Oncol 2004, 22:2336-2347.

18. Tabernero J, Rojo F, Calvo E, Burris H, Judson I, Hazell K, Martinelli E, Ramony CS, Jones S, Vidal L, Shand N, Macarulla T, Ramos FJ, Dimitrijevic S, Zoellner U, Tang P, Stumm M, Lane HA, Lebwohl D, Baselga J: Dose- and scheduledependent inhibition of the mammalian target of rapamycin pathway with everolimus: a phase I tumor pharmacodynamic study in patients with advanced solid tumors. J Clin Oncol 2008, 26:1603-1610.

19. Chow LW, Sun Y, Jassem J, Baselga J, Hayes DF, Wolff AC, Hachemi S, Cincotta M, Yu BW, Kong S, Moore L: Phase 3 study of temserolimus with letrozole 975 or letrozole alone in postmenopausal women with locally advanced or metastatic breast cancer. (Abstract 6091) Breast Cancer Res Treat 2006, 100(suppl 1):339.

20. Kurmasheva RT, Huang S, Houghton PJ: Predicted mechanisms of resistance to mTOR inhibitors. Br J Cancer 2006, 95:955-960.

21. Johnston SR: New strategies in estrogen receptor-positive breast cancer. Clin Cancer Res 2010, 16:1979-1987.

22. O'Reilly KE, Rojo F, She QB, Solit D, Mills GB, Smith D, Lane H, Hofmann F, Hicklin DJ, Ludwig DL, Baselga J, Rosen N: mTOR inhibition induces upstream receptor tyrosine kinase signaling and activates Akt. Cancer Res 2006, 66:1500-1508.

23. Carracedo A, Baselga J, Pandolfi PP: Deconstructing feedback-signaling networks to improve anticancer therapy with mTORC1 inhibitors. Cell Cycle 2008, 7:3805-3809.

24. Sun SY, Rosenberg LM, Wang X, Zhou Z, Yue P, Fu H, Khuri FR: Activation of Akt and elF4E survival pathways by rapamycin-mediated mammalian target of rapamycin inhibition. Cancer Res 2005, 65:7052-7058.

25. Awada A, Cardoso F, Fontaine C, Dirix L, De Greve J, Sotiriou C, Steinseifer J, Wouters C, Tanaka C, Zoellner U, Tang P, Piccart M: The oral mTOR inhibitor RAD001 (everolimus) in combination with letrozole in patients with advanced breast cancer: results of a phase I study with pharmacokinetics. Eur J Cancer 2008, 44:84-91.

26. Baselga J, Campone M, Piccart M, Burris HA, Rugo HS, Sahmoud T, Noguchi S, Gnant M, Pritchard Kl, Lebrun F, Beck JT, Ito Y, Yardley D, Deleu I, Perez A, Bachelot T, Vittori L, Xu Z, Mukhopadhyay P, Lebwohl D, Hortobagyi GN: Everolimus in postmenopausal hormone-receptor-positive advanced breast cancer. N Engl I Med 2012, 366:520-529.

27. Bachelot T, Bourgier C, Cropet C, Ray-Coquard I, Ferrero JM, Freyer G, Abadie-Lacourtoisie S, Eymard JC, Debled M, Spaeth D, Legouffe E, Allouache D, El Kouri C, Pujade-Lauraine E: Randomized phase II trial of everolimus in combination with tamoxifen in patients with hormone receptor-positive, human epidermal growth factor receptor 2-negative metastatic breast cancer with prior exposure to aromatase inhibitors: a GINECO study. J Clin Oncol 2012, 30:2718-2724.

28. Ciruelos E, Cortes-Funes H, Ghanem I, Manso L, Arteaga C: Role of inhibitors of mammalian target of rapamycin in the treatment of luminal breast cancer. Anticancer Drugs 2013, 24:769-780. 
29. Feldman ME, Apsel B, Uotila A, Loewith R, Knight ZA, Ruggero D, Shokat KM: Active-site inhibitors of mTOR target rapamycin-resistant outputs of mTORC1 and mTORC2. PLOS Biol 2009, 7:e38.

30. Guichard SM, Howard Z, Heathcote D, Roth M, Hughes G, Curwen J, Yates J, Logie A, Holt S, Chresta CM, Davies BR, Malagu K, Hummerstone M, Pass SL, Green S, Pass M: AZD2014, a dual mTORC1 and mTORC2 inhibitor is differentiated from allosteric inhibitors of mTORC1 in ER+ breast cancer. In Proceedings AACR 103rd Annual Meeting, Volume 72, 2012:917.

31. Garcia-Echeverria C: Allosteric and ATP-competitive kinase inhibitors of mTOR for cancer treatment. Bioorg Med Chem Lett 2010, 20:4308-4312.

32. Benjamin D, Colombi M, Moroni C, Hall MN: Rapamycin passes the torch: a new generation of mTOR inhibitors. Nat Rev Drug Discov 2011, 10:868-880.

33. Naing A, Aghajanian C, Raymond E, Olmos D, Schwartz G, Oelmann E, Grinsted L, Burke W, Taylor R, Kaye S, Kurzrock R, Banerji U: Safety, tolerability, pharmacokinetics and pharmacodynamics of AZD8055 in advanced solid tumours and lymphoma. Br J Cancer 2012, 107:1093-1099.

34. Knowlden JM, Hutcheson IR, Jones HE, Madden T, Gee JM, Harper ME, Barrow D, Wakeling AE, Nicholson Rl: Elevated levels of epidermal growth factor receptor/c-erbB2 heterodimers mediate an autocrine growth regulatory pathway in tamoxifen-resistant MCF-7 cells. Endocrinology 2003, 144:1032-1044.

35. Nicholson RI, Hutcheson IR, Hiscox SE, Knowlden JM, Giles M, Barrow D, Gee $J \mathrm{M}$ : Growth factor signalling and resistance to selective oestrogen receptor modulators and pure anti-oestrogens: the use of anti-growth factor therapies to treat or delay endocrine resistance in breast cancer. Endocr Relat Cancer 2005, 12:S29-S36.

36. Britton DJ, Hutcheson IR, Knowlden JM, Barrow D, Giles M, McClelland RA, Gee JM, Nicholson RI: Bidirectional cross talk between ERalpha and EGFR signalling pathways regulates tamoxifen-resistant growth. Breast Cancer Res Treat 2006, 96:131-146.

37. Jones $L$, Singer $V L$ : Fluorescence microplate-based assay for tumor necrosis factor activity using SYTOX Green stain. Anal Biochem 2001, 293:8-15.

38. Copp J, Manning G, Hunter T: TORC-specific phosphorylation of mammalian target of rapamycin (mTOR): phospho-Ser2481 is a marker for intact mTOR signaling complex 2. Cancer Res 2009, 69:1821-1827.

39. Hiscox S, Morgan L, Barrow D, Dutkowskil C, Wakeling A, Nicholson Rl: Tamoxifen resistance in breast cancer cells is accompanied by an enhanced motile and invasive phenotype: inhibition by gefitinib ('Iressa', ZD1839). Clin Exp Metastasis 2004, 21:201-212.

40. Nicholson RI, Staka C, Boyns F, Hutcheson IR, Gee JM: Growth factor-driven mechanisms associated with resistance to estrogen deprivation in breast cancer: new opportunities for therapy. Endocr Relat Cancer 2004, 11:623-641.

41. Knowlden JM, Hutcheson IR, Barrow D, Gee JM, Nicholson Rl: Insulin-like growth factor-I receptor signaling in tamoxifen-resistant breast cancer: a supporting role to the epidermal growth factor receptor. Endocrinology 2005, 146:4609-4618.

42. de Graffenried LA, Friedrichs WE, Russell DH, Donzis EJ, Middleton AK, Silva JM, Roth RA, Hidalgo M: Inhibition of mTOR activity restores tamoxifen response in breast cancer cells with aberrant Akt activity. Clin Cancer Res 2004, 10:8059-8067.

43. Sheri A, Martin LA, Johnston S: Targeting endocrine resistance: is there a role for mTOR inhibition? Clin Breast Cancer 2010, 10:S79-S85.

44. Johnston SR: Role of the mTOR pathway in endocrine resistant breast cancer-opportunities for novel combination strategies. In ASCO Educational Book, Alexandria, VA. 2009, 20-28

45. Leung E, Kannan N, Krissansen GW, Findlay MP, Baguley BC: MCF-7 breast cancer cells selected for tamoxifen resistance acquire new phenotypes differing in DNA content, phospho-HER2 and PAX2 expression, and rapamycin sensitivity. Cancer Biol Ther 2010, 9:717-724.

46. Dowling RJ, Topisirovic I, Fonseca BD, Sonenberg N: Dissecting the role of mTOR: lessons from mTOR inhibitors. Biochim Biophys Acta 2010, 1804:433-439.

47. Miller TW, Hennessy BT, Gonzalez-Angulo AM, Fox EM, Mills GB, Chen H, Higham C, Garcia-Echeverria C, Shyr Y, Arteaga CL: Hyperactivation of phosphatidylinositol-3 kinase promotes escape from hormone dependence in estrogen receptor-positive human breast cancer. J Clin Invest 2010, 120:2406-2413.

48. Sanchez CG, Ma CX, Crowder RJ, Guintoli T, Phommaly C, Gao F, Lin L, Ellis MJ: Preclinical modeling of combined phosphatidylinositol-3-kinase inhibition with endocrine therapy for estrogen receptor-positive breast cancer. Breast Cancer Res 2011, 13:R21.

49. Martin LA, Pancholi S, Farmer I, Guest S, Ribas R, Weigel MT, Thornhill AM, Ghazoui Z, A'Hern R, Evans DB, Lane HA, Johnston SR, Dowsett M:
Effectiveness and molecular interactions of the clinically active mTORC1 inhibitor everolimus in combination with tamoxifen or letrozole in vitro and in vivo. Breast Cancer Res 2012, 14:R132

50. Ray S, Fry MJ, Darbre PD: Enhanced sensitivity to rapamycin following long-term oestrogen deprivation in MCF-7, T-47-D and ZR-75-1 human breast cancer cells. J Endocrinol 2011, 208:21-29.

51. Drury SC, Detre S, Leary A, Salter J, Reis-Filho J, Barbashina V, Marchio C, Lopez-Knowles E, Ghazoui Z, Habben K, Arbogast S, Johnston S, Dowsett $\mathrm{M}$ : Changes in breast cancer biomarkers in the IGF1R/PI3K pathway in recurrent breast cancer after tamoxifen treatment. Endocr Relat Cancer 2011, 18:565-577.

52. Lacroix M, Leclercq G: Relevance of breast cancer cell lines as models for breast tumours: an update. Breast Cancer Res Treat 2004, 83:249-289.

53. Eccles SA, Aboagye EO, Ali S, Anderson AS, Armes J, Berditchevski F, Blaydes JP, Brennan K, Brown NJ, Bryant HE, Bundred NJ, Burchell JM, Campbell AM, Carroll JS, Clarke RB, Coles CE, Cook GJ, Cox A, Curtin NJ, Dekker LV, Dos Santos Silva I, Duffy SW, Easton DF, Eccles DM, Edwards DR, Edwards J, Evans D, Fenlon DF, Flanagan JM, Foster C: Critical research gaps and translational priorities for the successful prevention and treatment of breast cancer. Breast Cancer Res 2013, 15:R92.

54. Gee JM, Hutcheson IR: Understanding endocrine resistance: the critical need for sequential samples from clinical breast cancer and novel in vitro models. Breast Cancer Res 2005, 7:187-189.

55. Sweeney EE, McDaniel RE, Maximov PY, Fan P, Jordan VC: Models and mechanisms of acquired antihormone resistance in breast cancer: significant clinical progress despite limitations. Horm Mol Biol Clin Investig 2012, 9:143-163.

56. Cloughesy TF, Yoshimoto K, Nghiemphu P, Brown K, Dang J, Zhu S, Hsueh T, Chen Y, Wang W, Youngkin D, Liau L, Martin N, Becker D, Bergsneider M Lai A, Green R, Oglesby T, Koleto M, Trent J, Horvath S, Mischel PS, Mellinghoff IK, Sawyers CL: Antitumor activity of rapamycin in a Phase I trial for patients with recurrent PTEN-deficient glioblastoma. PLoS Med 2008, 5:e8

57. Meric-Bernstam F, Akcakanat A, Chen H, Do KA, Sangai T, Adkins F, GonzalezAngulo AM, Rashid A, Crosby K, Dong M, Phan AT, Wolff RA, Gupta S, Mills GB, Yao J: PIK3CA/PTEN mutations and Akt activation as markers of sensitivity to allosteric mTOR inhibitors. Clin Cancer Res 2012, 18:1777-1789.

58. Banerji U, Dean EJ, Gonzalez M, Greystoke AP, Basu B, Krebs M, Puglisi M, Grinsted L, Oelmann E, Burke W, et al: First in-human phase I trial of the dual mTORC1 and mTORc2 inhibitor AZD2014 in solid tumours. J Clin Oncol. 2012, 30s (abstract 3004).

59. Sini $P$, James D, Chresta C, Guichard S: Simultaneous inhibition of mTORC1 and mTORC2 by mTOR kinase inhibitor AZD8055 induces autophagy and cell death in cancer cells. Autophagy 2010, 6:4.

60. Willems L, Chapuis N, Puissant A, Maciel TT, Green AS, Jacque N, Vignon C, Park S, Guichard S, Herault O, Fricot A, Hermine O, Moura IC, Auberger P, Ifrah N, Dreyfus F, Bonnet D, Lacombe C, Mayeux P, Bouscary D, Tamburini J: The dual mTORC1 and mTORC2 inhibitor AZD8055 has anti-tumor activity in acute myeloid leukemia. Leukemia 2012, 26:1195-1202.

61. Marshall G, Howard Z, Dry J, Fenton S, Heathcote D, Gray N, Keen H, Logie A, Holt S, Smith P, Guichard SM: Benefits of mTOR kinase targeting in oncology: pre-clinical evidence with AZD8055. Biochem Soc Trans 2011, 39:456-459.

62. Delbaldo C, Albert S, Dreyer C, Sablin MP, Serova M, Raymond E, Faivre S: Predictive biomarkers for the activity of mammalian target of rapamycin (mTOR) inhibitors. Target Oncol 2011, 6:119-124.

63. Vignot S, Faivre S, Aguirre D, Raymond E: mTOR-targeted therapy of cancer with rapamycin derivatives. Ann Oncol 2005, 16:525-537.

64. Huo Y, ladevaia V, Yao Z, Kelly I, Cosulich S, Guichard S, Foster L, Proud CG: Stable isotope-labelling analysis of the impact of inhibition of the mammalian target of rapamycin on protein synthesis. Biochem J 2012, 444:141-151.

65. Chresta CM, Davies BR, Hickson I, Harding T, Cosulich S, Critchlow SE, Vincent JP, Ellston R, Jones D, Sini P, James D, Howard Z, Dudley P, Hughes G, Smith L, Maguire S, Hummersone M, Malagu K, Menear K, Jenkins R, Jacobsen M, Smith GC, Guichard S, Pass M: AZD8055 is a potent, selective, and orally bioavailable ATP-competitive mammalian target of rapamycin kinase inhibitor with in vitro and in vivo antitumor activity. Cancer Res 2010, 70:288-298.

66. Ghayad SE, Bieche I, Vendrell JA, Keime C, Lidereau R, Dumontet C, Cohen PA: $m$ TOR inhibition reverses acquired endocrine therapy resistance of 
breast cancer cells at the cell proliferation and gene-expression levels. Cancer Sci 2008, 99:1992-2003.

67. Yamnik RL, Digilova A, Davis DC, Brodt ZN, Murphy CJ, Holz MK: S6 kinase 1 regulates estrogen receptor alpha in control of breast cancer cell proliferation. J Biol Chem 2009, 284:6361-6369.

68. Yamnik RL, Holz MK: mTOR/S6K1 and MAPK/RSK signaling pathways coordinately regulate estrogen receptor alpha serine 167 phosphorylation. FEBS Lett 2010, 584:124-128.

69. Murphy LC, Seekallu SV, Watson PH: Clinical significance of estrogen receptor phosphorylation. Endocr Relat Cancer 2011, 18:R1-R14.

70. Yunokawa M, Koizumi F, Kitamura Y, Katanasaka Y, Okamoto N, Kodaira M, Yonemori K, Shimizu C, Ando M, Masutomi K, Yoshida T, Fujiwara Y, Tamura K: Efficacy of everolimus, a novel mTOR inhibitor, against basal-like triple-negative breast cancer cells. Cancer Sci 2012, 103:1665-1671.

71. Beeram M, Tan QT, Tekmal RR, Russell D, Middleton A, DeGraffenried LA: Akt-induced endocrine therapy resistance is reversed by inhibition of mTOR signaling. Ann Oncol 2007, 18:1323-1328.

72. Boulay A, Rudloff J, Ye J, Zumstein-Mecker S, O'Reilly T, Evans DB, Chen S, Lane HA: Dual inhibition of mTOR and estrogen receptor signaling in vitro induces cell death in models of breast cancer. Clin Cancer Res 2005, 11:5319-5328

doi:10.1186/bcr3604

Cite this article as: Jordan et al:: Impact of dual mTORC1/2 mTOR kinase inhibitor AZD8055 on acquired endocrine resistance in breast cancer in vitro. Breast Cancer Research 2014 16:R12.

\section{Submit your next manuscript to BioMed Central and take full advantage of:}

- Convenient online submission

- Thorough peer review

- No space constraints or color figure charges

- Immediate publication on acceptance

- Inclusion in PubMed, CAS, Scopus and Google Scholar

- Research which is freely available for redistribution 